\title{
Mercury bioaccumulation in estuarine food webs
}

\author{
Brian Fry ${ }^{1,2,4}$ AND Matthew M. Chumchal ${ }^{3}$ \\ ${ }^{1}$ Department of Oceanography and Coastal Sciences, Louisiana State University, Baton Rouge, Louisiana 70803 USA \\ ${ }^{2}$ Australian Rivers Institute, Griffith University, Nathan Campus, Kessels Road, Queensland 4121 Australia \\ ${ }^{3}$ Biology Department, Texas Christian University, Fort Worth, Texas 76129 USA
}

\begin{abstract}
We tested for unintended mercury contamination problems associated with estuarine floodplain restoration projects of the Louisiana coastal zone, USA. Barataria Bay and Breton Sound are two neighboring deltaic estuaries that were isolated by levees from the Mississippi River about 100 years ago. These estuaries recently have been reconnected to the nutrient-rich Mississippi River, starting major river diversion (input) flows in 1991 for Breton Sound and in 2004 for Barataria Bay. We collected $>2100$ fish over five years from 20 stations in these estuaries to test two hypotheses about $\mathrm{Hg}$ bioaccumulation: $\left(H_{1}\right)$ Background $\mathrm{Hg}$ bioaccumulation in fish would be highest in low-salinity upper reaches of estuaries, and $\left(\mathrm{H}_{2}\right)$ recent river inputs to these upper estuarine areas would increase $\mathrm{Hg}$ bioaccumulation in fish food webs. For $H_{1}$, we surveyed fish $\mathrm{Hg}$ concentrations at several stations along a salinity gradient in Barataria Bay in 2003-2004, a time when this estuary lacked strong river inputs. Results showed that average $\mathrm{Hg}$ concentrations in fish communities were lowest (150 ng/g dry mass) in higher salinity areas and $\sim 2.4 \times$ higher $(350 \mathrm{ng} / \mathrm{g})$ in low-salinity oligohaline and freshwater upper reaches of the estuary. For $\mathrm{H}_{2}$, we tested for enhanced $\mathrm{Hg}$ bioaccumulation following diversion onset in both estuaries. Fish communities from Breton Sound that had long-term ( $>10$ years) diversion inputs had $\sim 1.7 \times$ higher average $\mathrm{Hg}$ contents of $610 \mathrm{ng} / \mathrm{g} \mathrm{Hg}$ vs. $350 \mathrm{ng} / \mathrm{g}$ background values. Shorter-term diversion inputs over 2-3 years in upper Barataria Bay did not result in strong $\mathrm{Hg}$ enrichments or stable $\mathrm{C}$ isotope increases seen in Breton Sound, even though N and S stable-isotope values indicated strong river inputs in both estuaries. It may be that epiphyte communities on abundant submerged aquatic vegetation (SAV) are important hotspots for $\mathrm{Hg}$ cycling in these estuaries, and observed lesser development of these epiphyte communities in upper Barataria Bay during the first years of diversion inputs may account for the lessened $\mathrm{Hg}$ bioaccumulation in fish. A management consideration from this study is that river restoration projects may unintentionally fertilize SAV and epiphyte-based food webs, leading to higher $\mathrm{Hg}$ bioaccumulation in river-impacted floodplains and their food webs.
\end{abstract}

Key words: carbon; estuaries; fish; food webs; isotopes; largemouth bass; Louisiana, USA; mercury; Mississippi River; nitrogen; sulfur; wetlands.

\section{INTRODUCTION}

This 21 st century is experiencing a global perturbation experiment, with human population expansion and energy consumption combining to stress most landscapes and ecosystems (Gaffney 2009). Ecologists are increasingly forced to think about restoration of already altered systems, but there are many questions about whether systems can be returned to undisturbed, natural, or baseline conditions. Restoration may be most successful in preventing further deterioration and departures from background conditions, but restoration can also create new problems. This study concerns reconnection of river systems with historical floodplains, a seemingly laudable objective for re-creation of a holistic landscape that has been perturbed by river levee systems designed to aid

Manuscript received 20 May 2011; revised 10 October 2011; accepted 12 October 2011. Corresponding editor: S. P. Faulkner.

${ }^{4}$ E-mail: b.fry@griffith.edu.au human navigation and flood control. The levee system surrounding the Mississippi River has been estimated to be one of the largest human-made structures in the world, and breaching these levees to reintroduce river water to Louisiana floodplain estuaries was only begun after decades of discussion and legislation (Fremling et al. 1989, Turner and Boyer 1997, Day et al. 2009). The legislation governing diversions of Mississippi River water to estuaries focused on salinity control for increased oyster yields, but the resulting diversions now are often viewed in restoration terms (Turner 2009). This study focused on a possible unintended consequence of river diversions, namely increased $\mathrm{Hg}$ contamination of estuarine fish and shellfish. These animals are important to many Louisiana coastal residents who benefit from, consume, and market an abundant harvest of local seafood (Katner et al. 2010).

Mercury bioaccumulation in fish is a recognized health concern in many aquatic systems (NRC 2000), with fish-sampling programs designed to identify water 
bodies with significant $\mathrm{Hg}$ contaminant loads. Mobilization of fossil $\mathrm{Hg}$ reserves, especially by burning of coal, has increased $\mathrm{Hg}$ deposition worldwide (NRC 2000, Pacyna and Pacyna 2002, Driscoll et al. 2007, Drenner et al. 2011), and related anthropogenic additions of sulfate also seem to be increasing activities of the main agents of mercury methylation, the anaerobic sulfate-reducing bacteria. These bacteria may methylate $\mathrm{Hg}$ in a slow side reaction at $1 / 1000$ the rate of overall sulfate reduction, and sulfate reducers growing at or near redox interfaces may be most important for methylation and $\mathrm{Hg}$ contamination of shallow-water food webs (Benoit et al. 1998, 1999, Cleckner et al. 1999, Ullrich et al. 2001).

Diversions of Mississippi River water into upper estuarine reaches may increase the amount of habitat at risk for high methyl $\mathrm{Hg}$ production in Louisiana, USA, through several mechanisms. The Mississippi River contains $\sim 350-500 \mathrm{mmol} / \mathrm{m}^{3}$ sulfate (Bryan et al. 1992) and has low salinity, $<0.2$ practical salinity units (psu). Wetland habitats that have $100-1000 \mathrm{mmol} / \mathrm{m}^{3}$ sulfate levels are among the habitats with the highest $\mathrm{Hg}$ levels in fish because these areas exhibit significant sulfate reduction, but accumulate only low-to-moderate amounts of sulfide that can bind to $\mathrm{Hg}$ and make it unavailable for further bacterial cycling (Benoit et al. 1998, 1999). Diversion water currently contains high levels of N and P nutrients (Turner and Rabalais 1991, Turner et al. 2007, Day et al. 2009), and when river water floods existing wetlands, nutrients could promote the growth and expansion of submerged aquatic vegetation (SAV) habitats, stimulating methyl $\mathrm{Hg}$ production in associated epiphyte communities. Elevated mercury methylation and fish mercury loads have been reported for epiphyte-rich macrophyte communities in the Florida Everglades (Cleckner et al. 1998, 1999) and generally in wetlands similar to those found in upper Louisiana estuaries (Chumchal et al. 2008, Chumchal and Hambright 2009). Finally, the flooding Mississippi River water is a source of mercury for our study areas (Meade 1995, Rice et al. 2009).

We conducted a five-year study in coastal Louisiana to test (1) whether background $\mathrm{Hg}$ bioaccumulation in fish would be highest in low-salinity upper reaches of estuaries and (2) whether increased river inputs to estuaries could increase $\mathrm{Hg}$ bioaccumulation in fish food webs. Other recent $\mathrm{Hg}$ studies in Louisiana have focused on describing $\mathrm{Hg}$ cycling in water and sediments (Kongchum et al. 2004, Hall et al. 2008). Our study complements those investigations, but uses fish biosentinels to test for spatial patterns of $\mathrm{Hg}$ contamination in river-impacted food webs, building on observations that fish $\mathrm{Hg}$ measurements integrate many aspects of $\mathrm{Hg}$ dynamics in aquatic ecosystems (Porcella 1994, Hall et al. 1997, Leaner and Mason 2002, Wiener et al. 2003). Fish from the areas we studied have been estimated to have the lowest $\mathrm{Hg}$ levels in Louisiana (Katner et al. 2010), and our study tested for increases above this low background.
Besides $\mathrm{Hg}$, we also studied stable $\mathrm{N}, \mathrm{C}$, and $\mathrm{S}$ isotopes in estuarine fish. This combination of isotopes helps describe fish diets and trophic level (Kidd 1998, Fry 2002b, 2006). The combined isotope approach can help define the salinity regime that fish have recently inhabited (Fry 2002a) and also can identify low-salinity fish and food webs impacted by diversions (Fry 2002b, Wissel and Fry 2005).

\section{Study area}

We sampled fish and grass shrimp at 20 main locations in the Louisiana coastal plain during the course of this multiyear study. Locations included a salt marsh pond and nearby bay in lower Terrebonne Bay (see Fry et al. 2003 for map), three stations in lower Barataria Bay nearest the Gulf of Mexico, 10 stations in upper Barataria Bay, six stations in Breton Sound, and one station in the Mississippi River (Fig. 1). These stations all are within the Mississippi River deltaic plain, and the estuaries were formed over the last several thousand years by overbank flooding and mud deposition from the Mississippi River (Day et al. 2009). In the last 100 years, an extensive set of levees has been constructed along the Mississippi River, isolating these estuaries from the river. But starting in 1991 in Upper Breton Sound, the U.S. Corps of Engineers has constructed large, multi-gate structures in the levee system to reintroduce or divert Mississippi River water back into local estuaries. Water flows through the diversion structures into a series of lakes and canals in upper estuaries and exerts many effects on local biology (Day et al. 2009). We sampled fish at six upper-estuary stations in Breton Sound during September 2004 and May 2005 to assess Hg impacts in this estuary that had long term ( $>13$ year) exposure to river influences downstream of a diversion at Caernarvon near New Orleans.

A second major diversion structure has been built at Davis Pond at the head of Barataria estuary. This structure started operation in 2003, but due to various engineering problems, full and regular operation of this structure was delayed until the fall of 2005, after Hurricane Katrina. Our fish-sampling scheme in Barataria Bay began in 2003 and 2004 when diversion impacts were minimal and small, respectively, and continued in 2006 and 2007 after full operation of the diversion had commenced. River water entering at Davis Pond proceeds through a large cypress swamp and holding pond before entering the Lake Cataouatche area, the main river impact area in upper Barataria Bay sampled in this study. Stations in this impact area included Lake Cataouatche North and Central, Couba Island North and South, and Gulf Canal (Fig. 1). We also sampled extensively within the next downstream water body, Lake Salvador, a lake that had little detectable impact from the diversion (based on particulate organic matter [POM]; B. Fry, unpublished observations). Shorelines stations in eastern and western Lake Salvador were sampled in each year, though the 


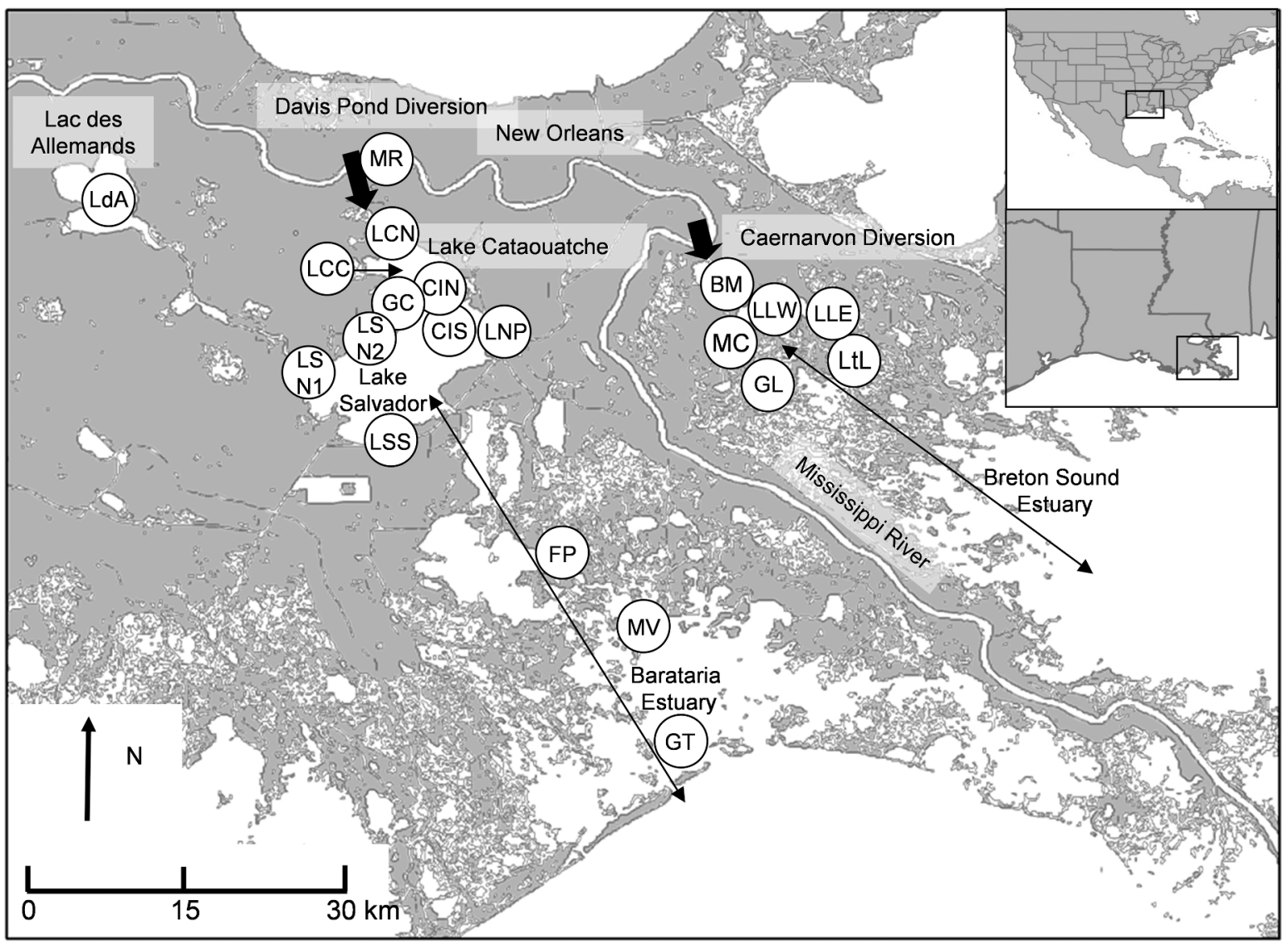

FIG. 1. Sample sites near New Orleans in the two Louisiana estuaries: Barataria Bay and Breton Sound, USA. Key to sites: BM, Big Mar; CIN, Couba Island North; CIS, Couba Island South; GC, Gulf Canal; GL, Grand Lake western shore; GT, Grand Terre; FP, Fisherman's Point; LdA, Lac des Allemands; LCC, Lake Cataouatche Central; LCN, Lake Cataouatche North; LLW, Lake Leary West; LLE, Lake Leary East; LS N1, Lake Salvador North Marsh 1; LS N2, Lake Salvador North Marsh 2; LSS, Lake Salvador South shoreline sites; LtL, Little Lake north shore; LNP, Lafitte National Park in Kenta Canal; MR, Mississippi River at Davis Pond diversion structure; MV, Manila Village; and MC, Manuel's Canal.

locations of these stations shifted according to field conditions. Two other stations functioned as control stations throughout the study: Kenta Canal, which is a backwater site in Jean Lafitte National Park to the east of Lake Salvador; and also Lac des Allemands to the west of Lake Salvador. Lac des Allemands is a freshwater lake upstream of the Davis Pond diversion, although in late summer saline waters sometimes enter this lake from further down the estuary. Lower estuary, higher salinity stations in Barataria Bay included Fisherman's Point, Manila Village, and Grand Terre (Fig. 1).

\section{Methods}

Fish were collected 2003-2007 during one-week expeditions made in mid- to late-summer, July-October, with the exception that some spring collections were made in 2003 in Barataria Bay and in Breton Sound during April 2005. Common names are used for fish species throughout the text; scientific names for these species are given in Table 1. Additional stations were sampled for grass shrimp (Palaemonetes sp.) in Breton Sound during 2000-2001 (Wissel and Fry 2005). Over the five-year study period, 67 collections at individual stations were made at upper-estuary stations, and nine collections were made at lower estuary stations. At each station, 30-100 individual fish were collected to represent the range of species, with up to six individuals per species collected to represent a size range, from smallest to largest. Most fish were 5-50 cm total length, although individuals of some species such as spotted gar and common carp were larger $(40-80 \mathrm{~cm}$ and $70-120 \mathrm{~cm}$ total length, respectively), and some species such as killifish and western mosquitofish were smaller $(1-3 \mathrm{~cm}$ total length).

Animals were collected with a boat-mounted electrofishing unit from riverine and low-salinity estuarine sites; gill nets, seines, and sweep nets were used to collect animals from the more marine portions of estuaries. Fish collected by gill netting were generally dead at the time of collection and frozen shortly thereafter. Electro- 
shocked and netted animals were placed in an ice bath at the time of collection, and then transported to the laboratory where they were frozen.

Later processing in the laboratory generally involved preparing dry samples according to protocols typically used in isotope laboratories. Specifically, laboratory work included thawing fish, measuring total lengths and blotted wet mass, and then dissection of white muscle tissue from the dorsal areas using a stainless-steel knife rinsed in deionized water (DI). Muscle tissue was cleaned by rinsing in running tap water, then placed in glass vials and allowed to soak $15-60 \mathrm{~min}$ in DI to remove salt. The soak water was discarded, tissues were dried at $60^{\circ} \mathrm{C}$, and then pulverized with a Wig-L-Bug automated grinder (Dentsply International, York, Pennsylvania, USA).

To determine if these methods typically used to prepare isotope samples could be used to prepare samples for $\mathrm{Hg}$ analysis, 30 individual fish for a methods comparison were collected on 10-12 April 2005 from three sites within upper Breton Sound and from the Mississippi River. Dry samples were processed as described in the previous paragraph, and wet samples were processed according to EPA protocols (U.S. EPA 1998) at a field dock as follows. Muscle tissue was dissected in the field with a clean stainless-steel knife. A sample of dorsal muscle tissue was dissected from the right and left side of each fish. One sample was used for the wet tissue analysis and the other sample was used for the dry-tissue analysis. Tissue samples were placed individually into plastic bags and stored on ice until being transported to the laboratory and frozen. The wet mass (wm) of each tissue was determined by immediately weighing the tissue after it was removed from its plastic bag. The dry mass $(\mathrm{dm})$ of each tissue was determined after the tissue was dried to a constant mass in a drying oven at $60^{\circ} \mathrm{C}$. Water mass of each tissue was estimated by subtracting $\mathrm{dm}$ from wm.

Fish were analyzed as individuals and grass shrimp as composites $(N=10 /$ sample $)$ for stable isotopes $\left(\delta^{13} \mathrm{C}\right.$, $\delta^{15} \mathrm{~N}$, and $\delta^{34} \mathrm{~S}$ ) following established procedures (Fry 2007, 2008), and also for total $\mathrm{Hg}$ as follows. Total mercury analyses were performed with a direct mercury analyzer (DMA-80; Milestone, Monroe, Connecticut, USA) that uses thermal decomposition, gold amalgamation, and atomic absorption spectrometry (U.S. EPA 1998). Quality assurance included reference and duplicate samples. Reference materials from the National Research Council of Canada Institute for National Measurement (MESS-3, DORM-2, PACS-2, or TORT2) were analyzed approximately every 10 samples, and the mean percentage of recovery was $98.8 \% \pm 0.4 \%$ (mean $\pm 95 \% \mathrm{CI}, N=361$ ). Duplicate samples were analyzed approximately every 20 samples, and the mean relative percentage of difference was $5.8 \% \pm 2.0 \%$ ( $N=$ 181). We used total $\mathrm{Hg}$ as a proxy for $\mathrm{MeHg}$, the predominant form of $\mathrm{Hg}$ in fish (Wiener et al. 2003).
Statistical comparisons among means were done with $t$ tests and Fischer's least significant difference test within the software program Statgraphics Plus v5.1 (StatPoint Technologies 2008), with significant differences indicated when $P<0.05$.

Several chemical measurements reported here were based on community averages, with these averages based on 50-100 fish of 5-15 species per site and time, with at least three individuals of different sizes represented per species. Trophic level (TL) was estimated from the $\Delta^{15} \mathrm{~N}$ deviation from the local $\delta^{15} \mathrm{~N}$ community averages. Among the most commonly collected fish, bluegills had $\delta^{15} \mathrm{~N}$ values closest to community averages (about $-0.35 \% \delta^{15} \mathrm{~N}$ or -0.1 trophic levels vs. the overall average). Assuming an average trophic level value of 3.18 for bluegills obtained from Fishbase (available online), ${ }^{5} \mathrm{TL}$ was calculated as

$$
\mathrm{TL}=\Delta^{15} \mathrm{~N} / 3.4+3.18+0.1
$$

where $\Delta^{15} \mathrm{~N}=\delta^{15} \mathrm{~N}($ fish $)-\delta^{15} \mathrm{~N}$ (community average), $3.4 \%$ represents the increase in fish $\delta^{15} \mathrm{~N}$ per trophic level (Minagawa and Wada 1984, Vander Zanden and Rasmussen 2001), 3.18 is the bluegill trophic level, and 0.1 corrects for the measured offset in bluegill trophic level vs. the overall community averages.

\section{REsults \\ Sampling methods development}

In the $\mathrm{Hg}$ methods comparison involving preparation of wet and dry samples, $\mathrm{Hg}$ concentrations determined with dried tissues were $\sim 4.7 \times$ higher than those determined by wet techniques. This $4.7 \times$ factor represented the weighed water loss of the tissues upon drying, which was $78.6 \% \pm 0.6 \%$. After correcting for these differences in water mass, estimates of mercury from wet and dry tissues showed one-to-one correspondence (i.e., the slope of the line in Fig. 2 was not significantly different than $1, t=0.42, P=0.68$ and the $y$-intercept was not significantly different than $0, t=-0.24, P=$ 0.81). Minor discrepancies were evident for individual samples between the wet and dry determinations results and were possibly due to the fact that the wet and dry tissues were taken from opposite sides of the fish, and so were not truly splits of the same sample (see also Cizdziel al. 2002). Hg concentrations in this study are reported on a dry mass basis as $\mathrm{ng} / \mathrm{g} \mathrm{Hg}$ ( $\mathrm{ng} \mathrm{Hg} / \mathrm{g}$ dry mass), but can be converted to $\mathrm{ng} / \mathrm{g}$ wet mass by dividing by 4.7 .

We performed a further methodological check with natural samples where ecosystem $\mathrm{Hg}$ concentrations were very low. We reasoned that any contamination effects should be strongest for samples where $\mathrm{Hg}$ concentrations were low, and hence could obscure normal patterns such as expected higher $\mathrm{Hg}$ levels in fish than in invertebrates. This work with low- $\mathrm{Hg}$

\footnotetext{
${ }^{5}$ www.fishbase.org
} 
TABLE 1. Size and chemical measures for fish from Barataria Bay, Louisiana, USA, 2003-2007.

\begin{tabular}{|c|c|c|c|c|}
\hline Common name & Scientific name & Total length (mm) & $\mathrm{Hg}(\mathrm{ng} / \mathrm{g})$ & $\delta^{15} \mathrm{~N}_{\mathrm{AIR}}$ \\
\hline \multicolumn{5}{|l|}{ Upper Barataria } \\
\hline \multicolumn{5}{|l|}{ Centrarchids } \\
\hline Redear sunfish & Lepomis microlophus & $124 \pm 6(54)$ & $227 \pm 59(54)$ & $9.0 \pm 0.2(54)$ \\
\hline Bluegill & Lepomis macrochirus & $116 \pm 4(113)$ & $318 \pm 24(114)$ & $10.0 \pm 0.2(114)$ \\
\hline Longear sunfish & Lepomis megalotis & $128 \pm 4(3)$ & $459 \pm 68(3)$ & $10.2 \pm 1.5(3)$ \\
\hline Redspotted sunfish & Lepomis miniatus & $111 \pm 12(5)$ & $477 \pm 69(5)$ & $8.3 \pm 0.4(5)$ \\
\hline Largemouth bass & Micropterus salmoides & $159 \pm 8(144)$ & $545 \pm 24(144)$ & $10.9 \pm 0.1(142)$ \\
\hline Warmouth & Lepomis gulosus & $157 \pm 5(3)$ & $569 \pm 64(3)$ & $8.9 \pm 0.5(3)$ \\
\hline \multicolumn{5}{|l|}{ Other species } \\
\hline Striped mullet & Mugil cephalus & $227 \pm 11(53)$ & $33 \pm 2(53)$ & $8.2 \pm 0.2(53)$ \\
\hline Gulf menhaden & Brevoortia patronus & $70 \pm 4(17)$ & $49 \pm 3(17)$ & $8.8 \pm 0.3(17)$ \\
\hline Bay anchovy & Anchoa mitchilli & $51 \pm 2(8)$ & $98 \pm 20(8)$ & $10.8 \pm 0.3(8)$ \\
\hline Sheepshead & Archosargus probatocephalus & $307 \pm 31(3)$ & $157 \pm 35(3)$ & $11.6 \pm 0.3(3)$ \\
\hline Golden shiner & Notemigonus crysoleucas & $86 \pm 21(4)$ & $162 \pm 30$ & $7.5 \pm 1.1$ \\
\hline Ladyfish & Elops saurus & $173 \pm 9(17)$ & $174 \pm 26(17)$ & $11.1 \pm 0.3(17)$ \\
\hline Inland silverside & Menidia beryllina & $54 \pm 2(93)$ & $189 \pm 12(94)$ & $10.3 \pm 0.1(94)$ \\
\hline Needlefish & Strongylura marina & $181 \pm 16(4)$ & $249 \pm 56(4)$ & $12.8 \pm 0.5(4)$ \\
\hline American eel & Anguilla rostrata & $352 \pm 17(7)$ & $275 \pm 30(7)$ & $11.7 \pm 0.7(7)$ \\
\hline Freshwater drum & Aplodinotus grunniens & $451 \pm 11(3)$ & $332 \pm 37(3)$ & $12.6 \pm 1.6(3)$ \\
\hline Red drum & Sciaenops ocellatus & $406 \pm 57(10)$ & $343 \pm 56(10)$ & $12.0 \pm 0.3(10)$ \\
\hline Channel catfish & Ictalurus punctatus & $357 \pm 39(16)$ & $379 \pm 83(16)$ & $10.9 \pm 0.4(16)$ \\
\hline Spotted gar & Lepisosteus oculatus & $530 \pm 7(111)$ & $654 \pm 38(111)$ & $11.8 \pm 0.1(111)$ \\
\hline \multicolumn{5}{|l|}{ Lower Barataria } \\
\hline Striped mullet & Mugil cephalus & $197 \pm 30(3)$ & $23 \pm 3(3)$ & $10.1 \pm 1.2(3)$ \\
\hline Spot & Leiostomus xanthurus & $162 \pm 5(16)$ & $57 \pm 5(16)$ & $12.5 \pm 0.4(16)$ \\
\hline Gulf menhaden & Brevoortia patronus & $121 \pm 9(24)$ & $62 \pm 6(24)$ & $12.2 \pm 0.3(24)$ \\
\hline Gizzard shad & Dorosoma cepedianum & $152 \pm 26(4)$ & $84 \pm 24(4)$ & $13.1 \pm 1.0(4)$ \\
\hline Atlantic croaker & Micropogonias undulatus & $162 \pm 8(14)$ & $106 \pm 13(14)$ & $11.8 \pm 0.4(14)$ \\
\hline Pinfish & Lagodon rhomboides & $128 \pm 6(3)$ & $112 \pm 27(3)$ & $13.4 \pm 1.1(3)$ \\
\hline Jack & unknown & $110 \pm 3(3)$ & $122 \pm 10(3)$ & $14.2 \pm 0.2(3)$ \\
\hline Inland silverside & Menidia beryllina & $54 \pm 2(40)$ & $149 \pm 28(45)$ & $12.1 \pm 0.1(45)$ \\
\hline Atlantic needlefish & Strongylura marina & $300 \pm 89(4)$ & $203 \pm 26(4)$ & $14.7 \pm 0.7(4)$ \\
\hline Ladyfish & Elops saurus & $270 \pm 9(16)$ & $209 \pm 21(16)$ & $11.5 \pm 0.4(16)$ \\
\hline Hardhead catfish & Ariopsis felis & $254 \pm 28(16)$ & $360 \pm 74(16)$ & $13.4 \pm 0.3(16)$ \\
\hline
\end{tabular}

Notes: $\mathrm{N}, \mathrm{C}$, and $\mathrm{S}$ isotope values are given as $\delta^{15} \mathrm{~N}, \delta^{13} \mathrm{C}$, and $\delta^{34} \mathrm{~S}$, where $\delta^{\mathrm{H}} X=\left(R_{\mathrm{SA}} / R_{\mathrm{ST}}-1\right) \times 1000$, with $\mathrm{H}$ indicating the respective heavy isotope $\left({ }^{15} \mathrm{~N},{ }^{13} \mathrm{C}\right.$, or $\left.{ }^{34} \mathrm{~S}\right), X$ indicating the respective element $(\mathrm{N}, \mathrm{C}$, or $\mathrm{S}), R_{\mathrm{SA}}$ and $R_{\mathrm{ST}}$ indicating respective sample and standard ratio values of ${ }^{15} \mathrm{~N}:{ }^{14} \mathrm{~N},{ }^{13} \mathrm{C}:{ }^{12} \mathrm{C}$ and ${ }^{34} \mathrm{~S}:{ }^{32} \mathrm{~S}$, and standards are, respectively, nitrogen in air, Vienna PeeDee Belemnite carbonate, and Vienna Canyon Diablo troilite. Upper Barataria specimens are from control areas not affected by diversions. Values are means $\pm \mathrm{SE}$, with the number of individuals sampled $(N)$ in parentheses.

samples used animals collected from a salt marsh pond and adjacent bay where salinities average near 10 psu (i.e., from Pond 2A and Bay Henry, described in Fry et al. 2003). Results showed the expected higher average $\mathrm{Hg}$ values in fish of $54 \pm 6 \mathrm{ng} / \mathrm{g}$ (mean $\pm \mathrm{SE}, N=18$ juvenile fish that were each $<10 \mathrm{~cm}$ total length and of five species [bay anchovy, menhaden, croaker, bay whiff flounder, and mullet]) and significantly lower average values in invertebrates $20 \pm 1 \mathrm{ng} / \mathrm{g}$ (mean $\pm \mathrm{SE}, N=35$ individual and composite invertebrate samples of three species [brown shrimp Farfantepenaeus aztecus, grass shrimp, and Rangia clams]). Grass shrimp important in upper-estuary studies averaged $20 \pm 3 \mathrm{ng} / \mathrm{g}$ (mean $\pm \mathrm{SE}$, $N=6$ composite samples). Overall, these results were consistent with no or very low contamination in our preparation of dried samples, and consequently we adopted the dry-and-grind preparation procedure in our further work. These results also showed very low $\mathrm{Hg}$ concentrations (all samples were $<95 \mathrm{ng} / \mathrm{g}$ dry or $<20$ $\mathrm{ng} / \mathrm{g}$ wet) in fish and invertebrate from higher salinity portions of estuaries, i.e., from more marine waters.

\section{Food web and Hg patterns in Louisiana estuaries}

We collected samples in 2003 across the full length of Barataria Bay to test the general pattern of $\mathrm{Hg}$ distributions in estuarine fish communities. Sulfur isotopes in fish were used as internal salinity markers (Fry 2002a,b), with freshwater samples from the Mississippi River and from Lac des Allemands that lacks river input having the lowest average $\delta^{34} \mathrm{~S}$ values of $-3 \%$ to $5 \%$, while higher $\mathrm{S}$ isotope values of $10-18 \%$ were characteristic of fish from higher salinity waters where abundant seawater sulfate has a high $\delta^{34} \mathrm{~S}$ value near 21\%o (Fig. 3; Fry and Chumchal 2011).

Results for the 2003 community averages showed lower $\mathrm{Hg}$ concentrations in fish from the more marine, lower part of the estuary $(149 \pm 15 \mathrm{ng} / \mathrm{g}$; mean $\pm \mathrm{SE}, N$ $=135$ ) compared to fish from the oligohaline, upper Barataria system $(343 \pm 12 \mathrm{ng} / \mathrm{g}$; mean $\pm \mathrm{SE}, N=559)$. The upper Barataria community averages were quite similar in the following years of 2004-2007 at $361 \pm 16$ $\mathrm{ng} / \mathrm{g}$ (mean $\pm \mathrm{SE}, N=439$ ) for stations outside the influence of the Davis Pond diversion and generally to 
TABLE 1. Extended.

\begin{tabular}{cc}
\hline \hline$\delta^{13} \mathrm{C}_{\mathrm{VPDB}}$ & $\delta^{34} \mathrm{~S}_{\mathrm{VCDT}}$ \\
& \\
& \\
$-26.6 \pm 0.4(54)$ & $5.0 \pm 0.3(54)$ \\
$-25.5 \pm 0.3(114)$ & $5.0 \pm 0.3(113)$ \\
$-26.4 \pm 1.2(3)$ & $5.7 \pm 0.7(3)$ \\
$-28.2 \pm 0.3(5)$ & $6.9 \pm 0.6(5)$ \\
$-25.3 \pm 0.2(142)$ & $5.2 \pm 0.3(142)$ \\
$-26.9 \pm 0.3(3)$ & $6.2 \pm 0.6(3)$ \\
& \\
$-23.9 \pm 0.5(53)$ & $6.0 \pm 0.3(52)$ \\
$-25.9 \pm 0.6(17)$ & $9.4 \pm 0.5(17)$ \\
$-23.2 \pm 0.9(8)$ & $4.9 \pm 0.6(8)$ \\
$-23.2 \pm 0.3(3)$ & $9.6 \pm 3.1(3)$ \\
$-29.1 \pm 1.1(4)$ & $4.1 \pm 0.7(4)$ \\
$-23.7 \pm 0.3(17)$ & $8.3 \pm 0.5(17)$ \\
$-23.8 \pm 0.3(94)$ & $5.8 \pm 0.3(94)$ \\
$-23.8 \pm 1.6(4)$ & $8.1 \pm 2.4(4)$ \\
$-22.6 \pm 0.4(7)$ & $10.2 \pm 0.4(7)$ \\
$-22.5 \pm 0.4(10)$ & $8.5 \pm 2.5(3)$ \\
$-24.7 \pm 0.5(16)$ & $8.3 \pm 0.5(10)$ \\
$-23.8 \pm 0.2(11)$ & $6.3 \pm 0.4(16)$ \\
$-18.0 \pm 0.4(3)$ & $7.1 \pm 0.2(111)$ \\
$-21.1 \pm 0.6(16)$ & \\
$-21.3 \pm 0.3(24)$ & $11.8 \pm 0.6(16)$ \\
$-23.6 \pm 1.5(4)$ & $6.9 \pm 2.1(4)$ \\
$-21.1 \pm 0.5(14)$ & $11.2 \pm 0.6(14)$ \\
$-18.8 \pm 0.0(3)$ & $9.4 \pm 2.3(3)$ \\
$-20.2 \pm 0.2(3)$ & $14.5 \pm 0.4(3)$ \\
$-18.4 \pm 0.2(45)$ & $13.5 \pm 0.3(45)$ \\
$-20.3 \pm 0.9(4)$ & $14.4 \pm 1.0(4)$ \\
$-19.7 \pm 0.4(16)$ & $10.3 \pm 0.5(16)$ \\
& $12.8 \pm 0.8(16)$ \\
\hline &
\end{tabular}

the south and west of Lake Cataouatche. Thus, the overall background average for upper Barataria stations with little diversion impact during the 2003-2007 years was $351 \pm 10 \mathrm{ng} / \mathrm{g}$ (mean $\pm \mathrm{SE}, N=998)$. Comparative community sampling in upper Breton Sound during 2004-2005 showed the highest average Hg concentrations $(608 \pm 31 \mathrm{ng} / \mathrm{g}$; mean $\pm \mathrm{SE}, N=388$; Fig. 3). Patterns detected in the community averages subsequently were confirmed as robust by analysis of single species, including largemouth bass (Fig. 3B) and several other species (bluegills, mullet, redears, silversides, and grass shrimp; data not shown).

Some of the variation in $\mathrm{Hg}$ was linked to fish size, with larger fish tending to have higher $\mathrm{Hg}$ concentrations (Fig.4A, Table 1). However, centrarchids (sunfish and largemouth bass) that were abundant in upperestuary samples collected in and near SAV beds seemed to have especially high $\mathrm{Hg}$ concentrations. Compared to other fish collected at the same times and places, the centrarchids were not particularly large (Fig. 4A), nor did they have unusually high $\delta^{15} \mathrm{~N}$ values (Fig. 4B), which often are associated with high trophic levels and high $\mathrm{Hg}$ contents. Centrarchid trophic levels ranged from 3.0 to 3.5 (Fig. 5), in the mid-range of other fish species. The TL estimates for fish species shown in Fig. 5 were generally similar and not significantly different in the two separate estuaries (data not shown).

In contrast to the centrarchids, water-column and benthic-feeding fish of low trophic level (bay anchovy, menhaden, threadfin shad, mullet, and gizzard shad; Fig. 5) all had much lower average $\mathrm{Hg}$ concentrations $(<100 \mathrm{ng} / \mathrm{g})$. Overall, anomalously high $\mathrm{Hg}$ concentrations seemed mostly confined to the SAV-associated centrarchids, with only zooplankton-feeding silversides collected near SAV being an exception; silversides had relatively high average values $(189 \pm 12 \mathrm{ng} / \mathrm{g}$; mean \pm SE, $N=94$ ) in upper Barataria samples. The generally higher $\mathrm{Hg}$ concentrations in fish from SAV beds also were mirrored in results for various kinds of shrimp. In upper Barataria samples, grass shrimp collected from SAV averaged $\sim 5 \times$ higher in mercury concentration (150 ng/g) than three different benthic shrimp species that all had much lower $\mathrm{Hg}$ concentrations (averages of $30-40 \mathrm{ng} / \mathrm{g})$.

\section{Effects of freshwater diversions}

The opening of the Davis Pond diversion in Upper Barataria Bay let us evaluate development of riverimpacted food webs in upper estuarine systems, and especially whether higher $\mathrm{Hg}$ concentrations would develop at Upper Barataria sites as they had in Breton Sound. We focused on six fish species that were common in our collections and represented the range of trophic levels we encountered, from mullet and redear sunfish at low trophic levels, to bluegills and silversides at interme-

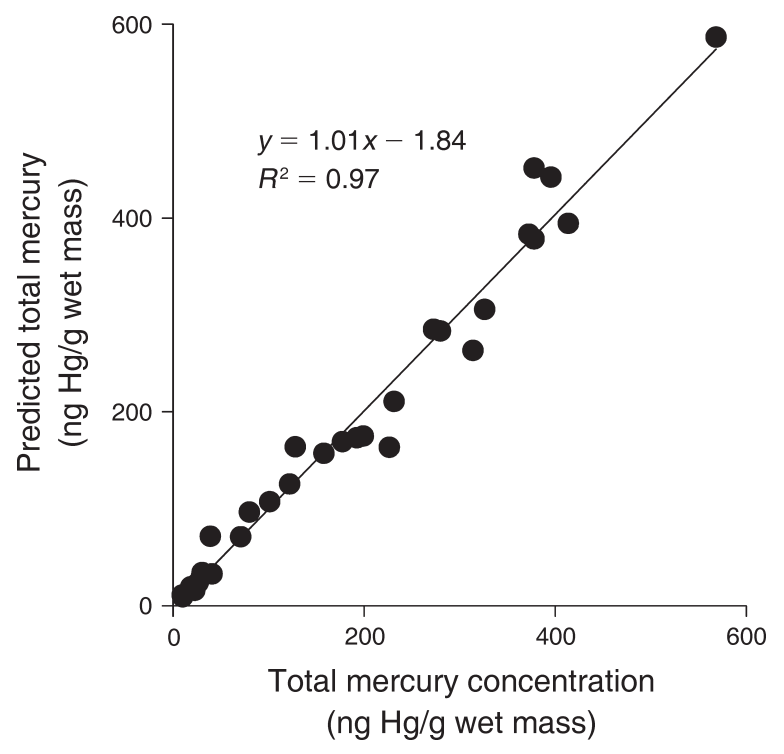

FIG. 2. Relationship between total mercury concentration determined from wet tissue and concentration predicted from dry tissues after a correction for water mass. Points represent 30 individual fish from 11 species collected in Breton Sound and the Mississippi River, 10-12 April 2005. 


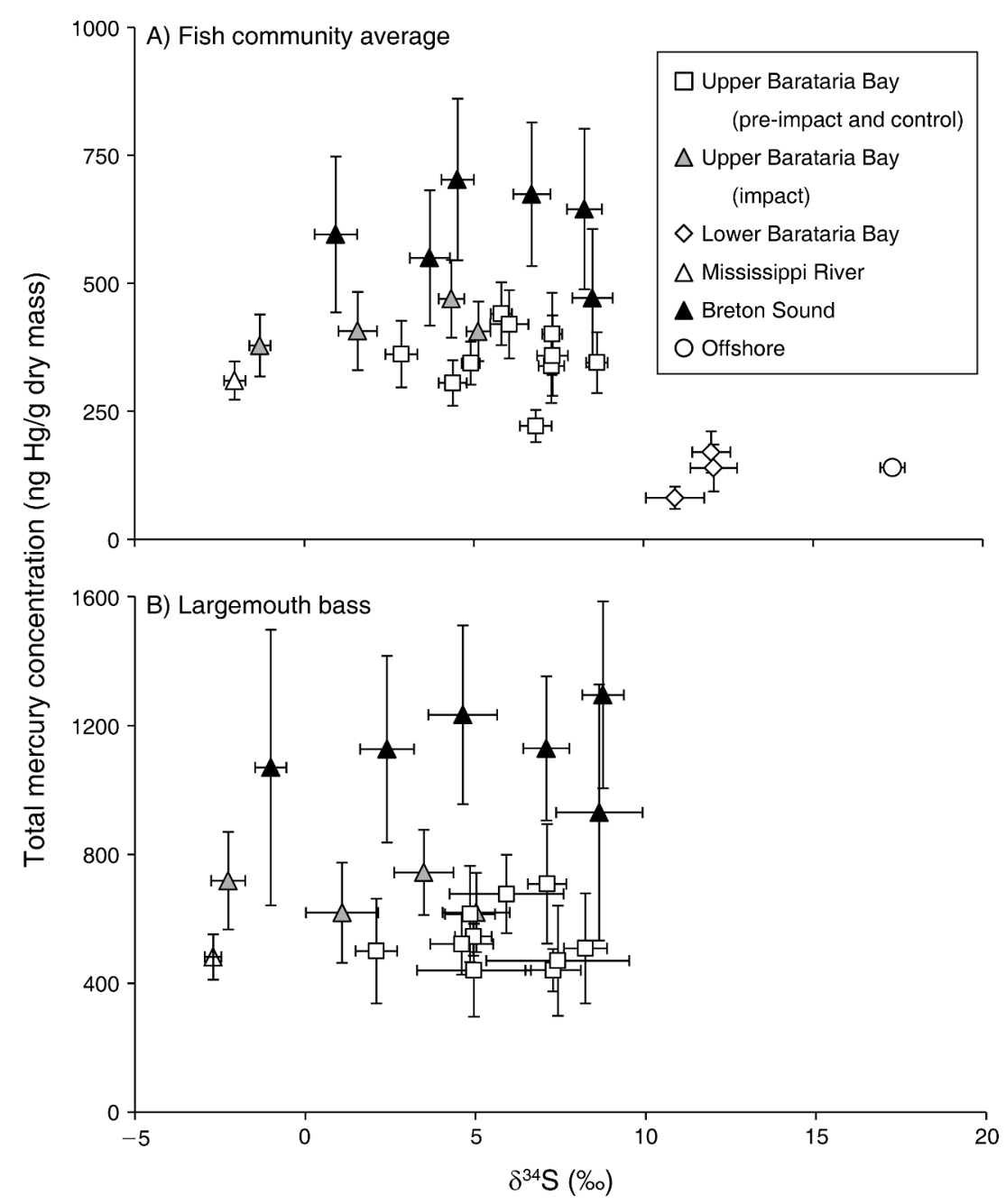

FIG. 3. Average $\mathrm{Hg}$ and $\delta^{34} \mathrm{~S}$ values by station for 2003-2007 (A) fish communities and (B) largemouth bass, showing that the highest $\mathrm{Hg}$ is found in fish from Breton Sound, which has the longest record of diversion impacts. Offshore samples are red snapper collected in a previous study (Wells et al. 2008a, b). Error bars are 95\% CL.

diate trophic levels, and largemouth bass and spotted gar at highest trophic levels (Fig. 5). For these species, we aggregated data into five station groups for comparisons by time and location: (1) the Mississippi River, all years; (2) upper Barataria control stations (Lac des Allemands, Lake Salvador and Kenta Canal in Jean Lafitte National Park), all years; (3) upper Barataria pre-impact stations in 2003, when diversion impacts were minimal (Lake Cataouatche $\mathrm{N}$ and Central stations, Gulf Canal and Couba Island North and South stations); (4) the same upper Barataria impact stations, but in 2004-2007, when diversions were stronger; and (5) Breton Sound that had long-term strong diversion impacts, all years sampled (2004 and 2005). Averages showed that fish in each species were of similar size in all five study groups and thus comparable (Fig. 6), and trophic level within each species was assumed constant. Consequently, we did not normalize for fish size or trophic level for our within-species comparisons of fish $\mathrm{Hg}$ concentrations. Within-species $\mathrm{Hg}$ differences were evaluated relative to background $\mathrm{Hg}$ levels for fish in the Mississippi River, or, in the case of redears and gar, which were rare in river samples, relative to background $\mathrm{Hg}$ levels measured in fish from upper Barataria Bay in 2003.

Breton Sound fish always had the highest $\mathrm{Hg}$ concentrations, and concentrations that were significantly (1.4-2.7×) higher than background (Table 2, Fig. 6). Fish from pre-impact upper Barataria Bay stations in 2003 and from upper Barataria Bay control stations in 2003-2007 had $\mathrm{Hg}$ concentrations that were not significantly different than background concentrations in 11 of 12 instances, with the exception that silversides collected in 2003 from pre-impact sites had significantly higher $\mathrm{Hg}$ values $(1.6 \times)$ than silversides collected in the Mississippi River (Table 2). After the start of full operation of the Davis Pond diversion, two of the six upper Barataria species showed significant $\mathrm{Hg}$ increases vs. background samples, i.e., mullet and largemouth 


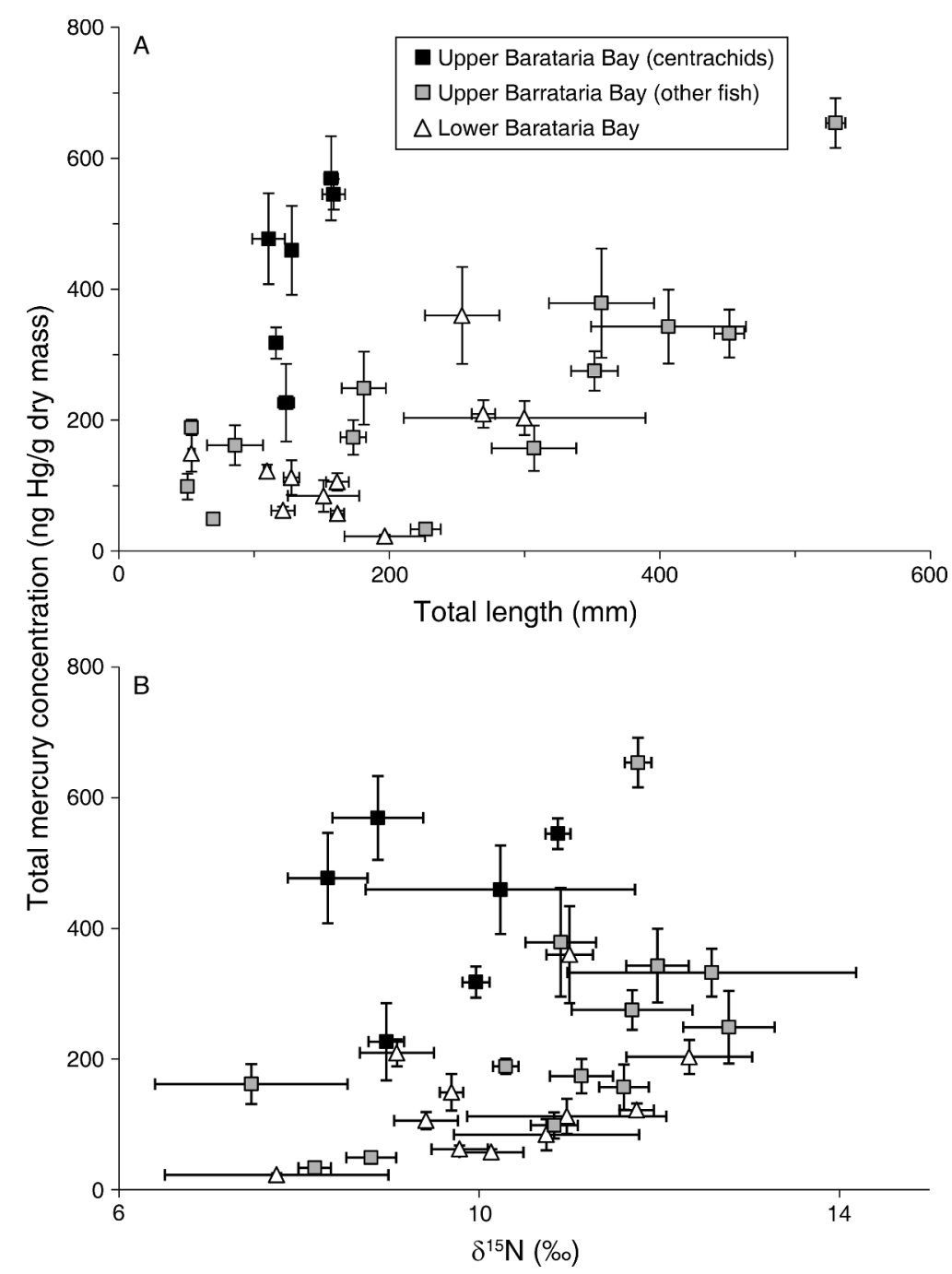

FIG. 4. Hg concentrations in fish from control areas in Barataria Bay that had little impact from the Davis Pond diversion and from lower Barataria Bay (stations FP, MV, and GT; see Fig. 1). Data are from Table 1, with N isotope data adjusted so that baseline $\delta^{15} \mathrm{~N}$ values were equal in both upper and lower bay samples, i.e., 2.4\%o was subtracted from lower bay animals based on the average $\delta^{15} \mathrm{~N}$ difference for three consumer species (mullet, menhaden, and silversides) collected in both upper and lower bays. Error bars are $\pm \mathrm{SE}$.

bass showed significant $1.3-1.4 \times$ increases in $\mathrm{Hg}$ vs. background (Table 2, Fig. 6).

Besides differences in $\mathrm{Hg}$, the fish community showed strong spatial trends in $\mathrm{N}$ and $\mathrm{C}$ isotopes, along two directions. The first salinity-related isotope trend extended from low $\delta^{15} \mathrm{~N}$ and $\delta^{13} \mathrm{C}$ values at background stations in upper Barataria that had little Mississippi River influence, through higher $\delta^{15} \mathrm{~N}$ and $\delta^{13} \mathrm{C}$ values for fish from high-salinity stations (Fig. 7). The second isotope trend was related to inputs of the Mississippi River, with river fish having highest $\delta^{15} \mathrm{~N}$ and lowest $\delta^{34} \mathrm{~S}$ (Fig. 7). Upper-estuary stations nearest diversion inputs in Breton Sound and Barataria Bay had intermediate, relatively high $\delta^{15} \mathrm{~N}$ and low $\delta^{34} \mathrm{~S}$, consistent with river inputs (Fig. 7, stations with labels BM and LLW from Breton Sound and stations LCN +
LCC and CIN from Barataria Bay; see Fig. 1 for station abbreviations). Closer examination of these stations showed that river nitrogen inputs were stronger in Breton Sound than in Barataria Bay because $\delta^{15} \mathrm{~N}$ values were significantly higher at the near-diversion stations BM and LLW in Breton Sound than at neardiversion stations LCN + LCC and CIN in upper Barataria Bay (Fig. 7). Stronger river influence in Breton Sound also led to strongly increased $\delta^{13} \mathrm{C}$ values, averaging near $-19 \%$, vs. the $-25 \%$ averages observed in the river itself; upper Barataria $\delta^{13} \mathrm{C}$ averages were quite similar to river averages (Fig. 7B, Table 2).

These differences in community isotope averages also were present at the species level (Table 2), with especially low $\delta^{34} \mathrm{~S}$ showing stronger Mississippi River inputs to all the diversion-impacted areas of upper Barataria Bay 


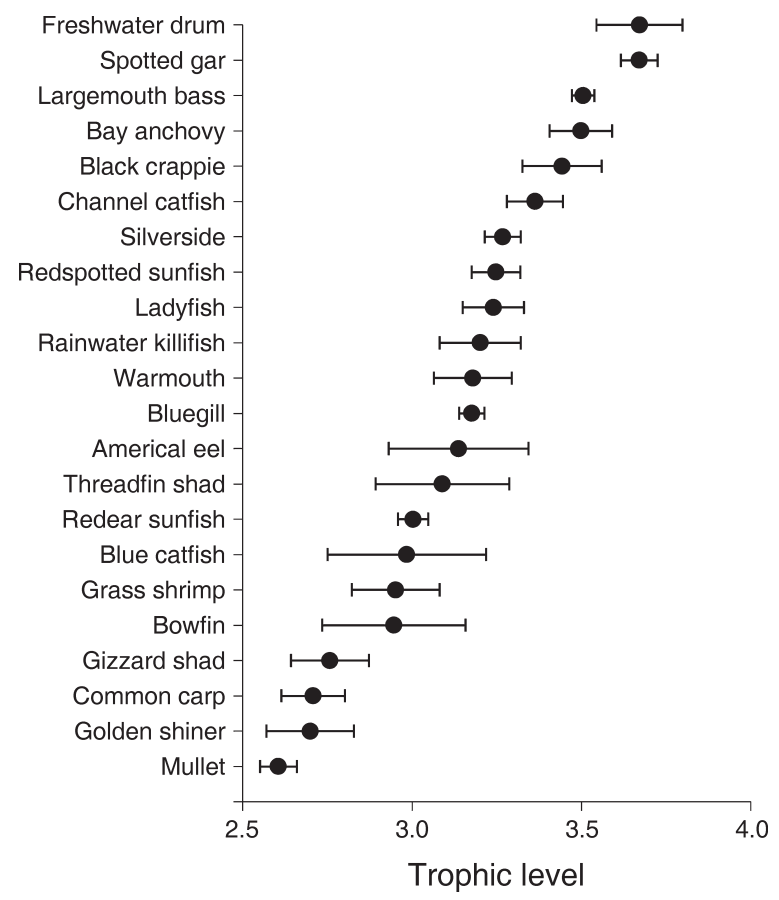

FIG. 5. Trophic level estimates for upper-estuary fish of this study, based on $\delta^{15} \mathrm{~N}$ values (see Methods). Error bars are $95 \%$ CL. Mullet include both striped and white mullet.

(Fig. 8). However, stronger river inputs in upper Barataria were not accompanied by stronger, significantly elevated $\delta^{15} \mathrm{~N}$ values typical of river fish (Fig. 8, Table 2), and stronger river inputs in upper Barataria also did not result in the high $\delta^{13} \mathrm{C}$ values (Fig. 9) found for fish from diversion-impacted Breton Sound. A few centrarchids (redear sunfish, bluegill, redspotted sunfish, and largemouth bass) collected in upper Barataria (Lake Cataouatche) SAV beds in summer 2007 had high $\delta{ }^{13} \mathrm{C}$ values $(-14 \%$ o to $-20 \%$ ) similar to those observed in Breton Sound, but average $\mathrm{Hg}$ concentrations for these Lake Cataouatche centrarchids were still low (130-230 $\mathrm{ng} / \mathrm{g}$ ) compared to the same species in Breton Sound, which had two to five times higher $\mathrm{Hg}$ values.

We sampled grass shrimp as one important prey item available to fish in the upper-estuary systems. Grass shrimp were abundant and easily collected in Breton Sound, averaging $269 \pm 10 \mathrm{ng} / \mathrm{g}($ mean $\pm \mathrm{SE}, N=62)$ for collections made in 2000-2001. These grass shrimp samples were routinely collected in triplicate, with $N=$ 10 shrimp per sample during a previous food web study in Breton Sound (Wissel and Fry 2005). In spite of the average nature of pooled samples, the triplicate grass shrimp samples still showed high variability, with CV $(=100 \times$ standard deviation/mean) of $19 \% \pm 5 \%$ (mean $\pm 95 \% \mathrm{CL}$ ) compared to $\mathrm{CV}$ of $3 \pm 3$ (mean $\pm 95 \% \mathrm{CL})$ for individual samples analyzed in triplicate. Grass shrimp were much rarer and difficult to find in the upper Barataria area, where composite samples averaged 136 $\pm 51 \mathrm{ng} / \mathrm{g}$ (mean $\pm \mathrm{SE}, N=7$ ) for collections made in
2003 plus control areas, and $178 \pm 27 \mathrm{ng} / \mathrm{g}$ (mean $\pm \mathrm{SE}$, $N=3$ ) for collections made in 2004-2007 impact areas. Grass shrimp abundance may be related to development of SAV communities, and field observations in 20062007 in Lake Cataouatche indicated that (1) large SAV beds had developed by summer 2006 (Green et al. 2007), (2) most of the SAV was Hydrilla, (3) there was little epiphyte growth on these plants, and (4) there were few grass shrimp in these SAV beds.

We also more closely examined the data for largemouth bass across the various study areas, finding that in each area, much of the $\mathrm{Hg}$ variation was present among relatively small 50-150 mm fish (Fig. 10, data bracketed by vertical dashed lines). There was a $>20 \times$ variation in $\mathrm{Hg}$ contents among individual fish in this size range, and areas impacted by diversions, especially, had a higher proportion of fish with highest 1000-2000 $\mathrm{ng} / \mathrm{g} \mathrm{Hg}$ concentrations. The frequency of these highest $>1000 \mathrm{ng} / \mathrm{g} \mathrm{Hg}$ fish increased from $0 \%$ to $2 \%$ in background samples from upper Barataria control areas and from the Mississippi River (Fig. 10A, C) to $18-24 \%$ for areas impacted by diversions (Fig. 10B, D). Close inspection of the data showed that these 50-150 mm fish with the highest $\mathrm{Hg}$ concentrations were not unusual in other measured parameters such as fish total length or $\mathrm{C}, \mathrm{N}$, and $\mathrm{S}$ isotopes. For example, $t$ tests for unpaired means showed that these fish with highest $\mathrm{Hg}$ concentrations $>1000 \mathrm{ng} / \mathrm{g}$ in diversion impacted areas (Fig. 10B, D) did not have significantly different $(P>0.05)$ sizes or trophic level (indicated by $\delta^{15} \mathrm{~N}$ values) vs. fish from the same areas that had lower $<1000 \mathrm{ng} / \mathrm{g} \mathrm{Hg}$ values. Overall, these smaller $50-150 \mathrm{~mm}$ largemouth bass were very common in SAV beds, and could be targeted in larger numbers in future work aimed at assessing $\mathrm{Hg}$ differences among sites and areas. A power analysis with randomized resampling of the $\mathrm{Hg}$ data for 50-150 mm fish shown in Fig. 10 showed that averaging three composite samples consisting each of 15 fish would provide enough power to measure significant statistical differences among areas.

\section{DisCusSION}

The main findings of this study were that fish $\mathrm{Hg}$ concentrations were higher in upper-estuary fish and highest in fish from Breton Sound, which experienced long-term inputs of diverted water from the Mississippi River. The strongest relationships we found that potentially explained enhanced $\mathrm{Hg}$ accumulation in estuarine food webs centered on grass shrimp and centrarchid sunfish that feed in SAV beds, and generally this work supports the idea that epiphyte communities in these SAV beds are important hotspots for $\mathrm{Hg}$ methylation. This type of hotspot problem has been documented in studies of $\mathrm{Hg}$ cycling in Everglades freshwater marshes (Cleckner et al. 1998, 1999, Bates et al. 2002), and a similar phenomenon of hotspots of $\mathrm{MeHg}$ production on scales of $<3 \mathrm{~m}$ has been observed in peat marshes (Mitchell et al. 2008). Inferred $\mathrm{Hg}$ 

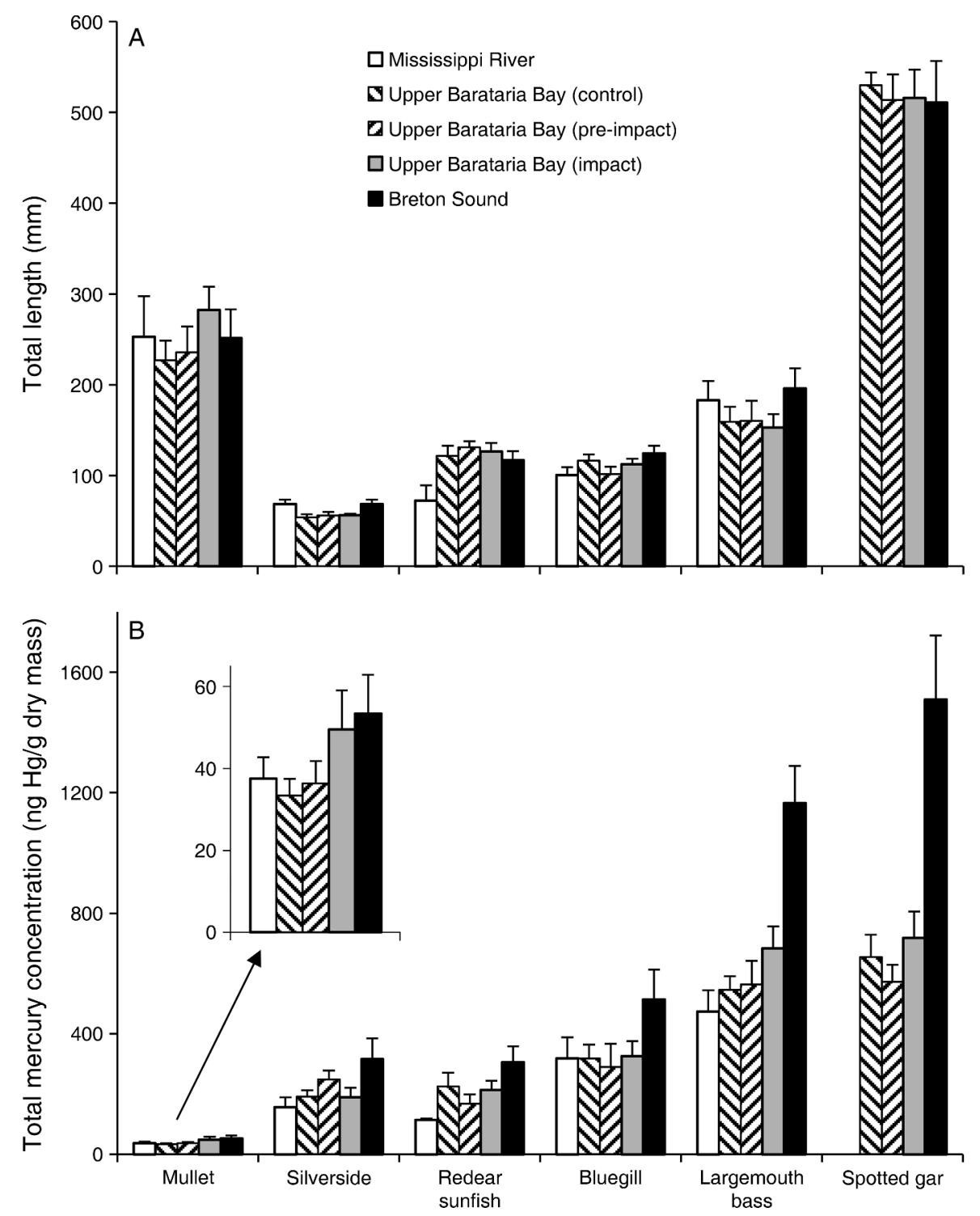

FIG. 6. Site comparisons for six fish species collected at upper-estuary stations: (A) total length and (B) Hg content. The inset shows an expanded view of mullet data. Mullet include both striped and white mullet. Error bars are $95 \%$ CL.

hotspots occurred in wetlands in our study, with wetlands generally recognized as important sites of mercury methylation (Driscoll et al. 2007). The next paragraphs discuss some of the detailed evidence we considered in concluding that hotspots are likely important in explaining the $\mathrm{Hg}$ bioaccumulation patterns we found. Our results provide a working hypothesis for the location of hotspots, but future work will be needed measuring $\mathrm{Hg}$ methylation and demethylation rates in epiphyte communities to confirm these inferences about hotspot locations and activities.

Our stable-isotope work showed strong isotope differences among riverine, lower-estuary, and upperestuary fish, consistent with strong overall residency and localization of fish movement in these estuarine systems.
Previous study of the particulate organic matter (POM) in the Breton Sound and Barataria Bay estuaries showed the same overall $\mathrm{C}$ and $\mathrm{N}$ isotope patterns documented here for fish, i.e., that the isotopes vary strongly with salinity and that there is a strong ${ }^{13} \mathrm{C}$ enrichment in upper Breton Sound vs. upper Barataria (Wissel et al. 2005). The overall similarity of isotope patterns in POM and fish indicates strongly that, on average, fish are resident at the same scale as water-borne POM that moves only passively with tides and river forcing. The presence of different $\mathrm{Hg}$ loads in individual fish and grass shrimp is thus not easily explained by transient movement because animals appeared to be largely resident as measured by isotopes. To account for variability in $\mathrm{Hg}$ contents of residents, it seems necessary 
TABLE 2. Chemical compositions and total lengths of six species by site.

\begin{tabular}{lcccc}
\hline \hline \multicolumn{1}{c}{ Site } & Mullet & Silversides & Redears & Bluegills \\
\hline a) Total mercury concentration (ng Hg/g dry mass) & & & \\
MR & $37 \pm 3(26)^{\mathrm{A}}$ & $157 \pm 16(20)^{\mathrm{A}}$ & $115 \pm 2(2)^{\mathrm{AB}}$ & $319 \pm 35(27)^{\mathrm{A}}$ \\
UBC 2003-2007 & $33 \pm 2(53)^{\mathrm{A}}$ & $190 \pm 12(93)^{\mathrm{A}}$ & $224 \pm 24(52)^{\mathrm{A}}$ & $318 \pm 24(114)^{\mathrm{A}}$ \\
UBP 2003 & $36 \pm 3(28)^{\mathrm{A}}$ & $248 \pm 15(51)^{\mathrm{B}}$ & $168 \pm 16(33)^{\mathrm{A}}$ & $290 \pm 40(48)^{\mathrm{A}}$ \\
UBI 2004-2007 & $49 \pm 5(19)^{\mathrm{B}}$ & $189 \pm 16(41)^{\mathrm{A}}$ & $214 \pm 16(73)^{\mathrm{A}}$ & $326 \pm 25(92)^{\mathrm{A}}$ \\
MBS & $53 \pm 5(29)^{\mathrm{B}}$ & $316 \pm 35(30)^{\mathrm{C}}$ & $306 \pm 27(74)^{\mathrm{B}}$ & $515 \pm 51(58)^{\mathrm{B}}$
\end{tabular}

b) Mercury relative enrichment factors ( $\mathrm{Hg}$ in sample fish/Hg in background reference fish) $\pm \mathrm{SE}$, where reference fish are from the Mississippi River, or for gar, from Upper Barataria 2003 collections

$\begin{array}{llllr}\text { MR } & 1.0 \pm 0.1 & 1.0 \pm 0.1 & 0.7 \pm 0.0 & 1.0 \pm 0.1 \\ \text { UBC 2003-2007 } & 1.0 \pm 0.1 & 1.2 \pm 0.1 & 1.3 \pm 0.2 & 1.0 \pm 0.1 \\ \text { UBP 2003 } & 1.0 \pm 0.1 & 1.6 \pm 0.1 & 1.0 \pm 0.1 & 1.0 \pm 0.1 \\ \text { UBI 2004-2007 } & 1.3 \pm 0.1 & 1.2 \pm 0.1 & 1.3 \pm 0.1 & 1.0 \pm 0.1 \\ \text { BS } & 1.4 \pm 0.1 & 2.0 \pm 0.2 & 1.8 \pm 0.2 & 1.6 \pm 0.2\end{array}$

c) Total length $(\mathrm{mm})$

MR

UBC 2003-2007

UBP 2003

UBI 2004-2007

BS

d) $\delta^{15} \mathrm{~N}(\%)$

MR

UBC 2003-2007

UBP 2003

UBI 2004-2007

BS

$$
\begin{aligned}
& 252 \pm 23(26)^{\mathrm{AB}} \\
& 227 \pm 11(53)^{\mathrm{A}} \\
& 236 \pm 15(28)^{\mathrm{AB}} \\
& 283 \pm 13(19)^{\mathrm{B}} \\
& 252 \pm 16(29)^{\mathrm{AB}}
\end{aligned}
$$

$1.8 \pm 0.2$

$1.6 \pm 0.2$

$$
\begin{aligned}
& 73 \pm 9(2)^{\mathrm{A}} \\
& 121 \pm 6(52)^{\mathrm{AB}} \\
& 131 \pm 4(32)^{\mathrm{B}} \\
& 127 \pm 5(73)^{\mathrm{AB}} \\
& 117 \pm 5(74)^{\mathrm{AB}}
\end{aligned}
$$

$13.1 \pm 0.1(2)^{\mathrm{C}}$

$9.0 \pm 0.2(52)^{\mathrm{A}}$

$8.7 \pm 0.2(33)^{\mathrm{A}}$

$9.9 \pm 0.2(73)^{\mathrm{B}}$

$10.3 \pm 0.2(74)^{\mathrm{B}}$ e) $\delta^{13} \mathrm{C}(\%)$

MR

UBC 2003-2007

UBP 2003

UBI 2004-2007 BS

f) $\delta^{34} \mathrm{~S}(\% \mathrm{o})$

MR

UBC 2003-2007

UBP 2003

UBI 2004-2007

BS

$$
\begin{aligned}
& 69 \pm 3(20)^{\mathrm{B}} \\
& 54 \pm 2(93)^{\mathrm{A}} \\
& 56 \pm 2(53)^{\mathrm{A}} \\
& 56 \pm 1(41)^{\mathrm{A}} \\
& 69 \pm 3(30)^{\mathrm{B}}
\end{aligned}
$$

$$
\begin{array}{r}
11.3 \pm 0.4(26)^{\mathrm{B}} \\
8.2 \pm 0.2(53)^{\mathrm{A}} \\
8.9 \pm 0.3(28)^{\mathrm{A}} \\
10.6 \pm 0.3(29)^{\mathrm{B}} \\
8.5 \pm 0.4(29)^{\mathrm{A}}
\end{array}
$$

$$
\begin{array}{r}
15.0 \pm 0.3(20)^{\mathrm{D}} \\
10.3 \pm 0.1(94)^{\mathrm{B}} \\
9.5 \pm 0.1(53)^{\mathrm{A}} \\
11.1 \pm 0.2(41)^{\mathrm{C}} \\
10.9 \pm 0.2(30)^{\mathrm{C}}
\end{array}
$$

$$
\begin{aligned}
& -24.9 \pm 0.4(20)^{\mathrm{AB}} \\
& -23.8 \pm 0.3(94)^{\mathrm{B}} \\
& -25.3 \pm 0.4(53)^{\mathrm{A}} \\
& -23.7 \pm 0.5(41)^{\mathrm{B}} \\
& -19.7 \pm 0.4(30)^{\mathrm{C}}
\end{aligned}
$$

$100.4 \pm 5(27)^{\mathrm{A}}$

$116.2 \pm 4(113)^{\mathrm{BC}}$

$101.3 \pm 4(47)^{\mathrm{A}}$

$112.4 \pm 3(92)^{\mathrm{AB}}$

$124.3 \pm 4(58)^{\mathrm{C}}$

$$
\begin{aligned}
& -21.7 \pm 0.5(26)^{\mathrm{B}} \\
& -23.9 \pm 0.5(53)^{\mathrm{A}} \\
& -23.0 \pm 0.5(28)^{\mathrm{AB}} \\
& -24.6 \pm 0.7(19)^{\mathrm{A}} \\
& -19.8 \pm 0.4(29)^{\mathrm{C}}
\end{aligned}
$$$$
\begin{aligned}
& -21.9 \pm 2.0(2)^{\mathrm{BC}} \\
& -26.6 \pm 0.4(52)^{\mathrm{A}} \\
& -25.6 \pm 0.3(33)^{\mathrm{A}} \\
& -24.1 \pm 0.4(73)^{\mathrm{B}} \\
& -20.1 \pm 0.2(74)^{\mathrm{C}}
\end{aligned}
$$

$$
\begin{array}{r}
-2.6 \pm 0.3(20)^{\mathrm{A}} \\
5.8 \pm 0.3(94)^{\mathrm{D}} \\
3.9 \pm 0.3(53)^{\mathrm{C}} \\
2.2 \pm 0.5(41)^{\mathrm{B}} \\
6.4 \pm 0.6(30)^{\mathrm{D}}
\end{array}
$$
$-5.6 \pm 0.1(2)^{\mathrm{A}}$
$5.0 \pm 0.4(52)^{\mathrm{D}}$
$4.3 \pm 0.4(33)^{\mathrm{CD}}$
$0.6 \pm 0.4(73)^{\mathrm{B}}$
$3.8 \pm 0.4(73)^{\mathrm{C}}$

$13.8 \pm 0.3(27)^{\mathrm{D}}$ $10.0 \pm 0.2(114)^{\mathrm{B}}$

$9.4 \pm 0.2(48)^{\mathrm{A}}$

$10.9 \pm 0.2(92)^{\mathrm{C}}$

$10.8 \pm 0.2(58)^{\mathrm{C}}$

$$
\begin{aligned}
& -26.9 \pm 0.5(27)^{\mathrm{A}} \\
& -25.5 \pm 0.3(114)^{\mathrm{B}} \\
& -26.0 \pm 0.2(48)^{\mathrm{AB}} \\
& -24.3 \pm 0.3(93)^{\mathrm{C}} \\
& -20.0 \pm 0.4(58)^{\mathrm{D}}
\end{aligned}
$$$$
\begin{aligned}
-3.0 & \pm 0.3(27)^{\mathrm{A}} \\
5.0 & \pm 0.3(113)^{\mathrm{C}} \\
4.7 & \pm 0.5(48)^{\mathrm{C}} \\
0.3 & \pm 0.4(92)^{\mathrm{B}} \\
4.5 & \pm 0.5(58)^{\mathrm{C}}
\end{aligned}
$$

Notes: Site abbreviations are: MR, Mississippi River; UBC, Upper Barataria controls; UBP, Upper Barataria pre-impact; UBI, Upper Barataria impact; and BS, Breton Sound. Mullet are striped and white mullet. Values are means \pm SE, with the number of individuals sampled $(N)$ in parentheses. Superscript letters indicate homogenous means $(P>0.05)$ by Fischer's least significant difference test.

to think about a patchy environment involving $\mathrm{Hg}$ hotspots.

The smallest relevant scale for $\mathrm{Hg}$ methylation is likely a microbial scale $<1 \mathrm{~mm}$; for example, with epiphytes growing on submerged macrophytes and sulfate-reducing bacteria growing between the epiphytes and macrophytes. In this microbial model, labile organic matter would be produced by epiphytes during the day, and sulfate reducers would use this organic matter at night when oxygen levels fall and more anaerobic conditions develop. Sulfides produced at night would be oxidized during daytime photosynthesis and not accumulate to trap $\mathrm{Hg}$ and prevent methylation. Photosynthetic and colorless sulfur bacteria also could be involved in this epiphyte community and could contribute to sulfide oxidation (Kuhl and Jorgensen 1992, Cleckner et al. 1999). This model of small-scale Hg hotspots may explain our observations that even composite triplicate samples of grass shrimp collected together at one time in a $30-\mathrm{m}$ area sometimes had quite different $\mathrm{Hg}$ concentrations. Mercury methylation hotspots could possibly occur in larger patches as well; for example, along longer shorelines where rafts of decomposing SAV sometimes accumulate. Lack of these types of epiphyte communities in the turbulent and turbid Mississippi River may account for the relatively low background $\mathrm{Hg}$ values found in fish from this river (Table 2; Katner et al. 2010). Low-oxygen conditions that develop in SAV patches (Colon-Gaud et al. 2004) may be important in controlling $\mathrm{Hg}$ methylation dynamics, and high turbulence and oxygenation of the Mississippi River may minimize hotspot formation.

In upper-estuary fish, $\mathrm{Hg}$ concentrations were generally highest in SAV-related centrarchids and spotted gar, low in benthic-feeding species such as mullet and gizzard shad, and also low in plankton-feeding species such as 
TABLE 2. Extended.

\begin{tabular}{|c|c|}
\hline Largemouth bass & Spotted gar \\
\hline $\begin{aligned} 475 & \pm 36(51)^{\mathrm{A}} \\
545 & \pm 24(144)^{\mathrm{A}} \\
563 & \pm 40(62)^{\mathrm{A}} \\
683 & \pm 37(130)^{\mathrm{B}} \\
1165 & \pm 63(78)^{\mathrm{C}}\end{aligned}$ & $\begin{aligned} 1468 & \pm 3(2)^{\mathrm{B}} \\
654 & \pm 38(111)^{\mathrm{A}} \\
572 & \pm 30(50)^{\mathrm{A}} \\
718 & \pm 45(49)^{\mathrm{A}} \\
1508 & \pm 109(34)^{\mathrm{B}}\end{aligned}$ \\
\hline $\begin{array}{l}1.0 \pm 0.1 \\
1.1 \pm 0.0 \\
1.2 \pm 0.1 \\
1.4 \pm 0.1 \\
2.5 \pm 0.1\end{array}$ & $\begin{array}{l}2.6 \pm 0.0 \\
1.1 \pm 0.1 \\
1.0 \pm 0.1 \\
1.3 \pm 0.1 \\
2.6 \pm 0.2\end{array}$ \\
\hline $\begin{array}{l}182.6 \pm 11(51)^{\mathrm{AB}} \\
158.9 \pm 8(144)^{\mathrm{A}} \\
160.2 \pm 11(61)^{\mathrm{A}} \\
152.8 \pm 8(113)^{\mathrm{A}} \\
196.3 \pm 11(78)^{\mathrm{B}}\end{array}$ & $\begin{array}{l}560 \pm 57(2)^{\mathrm{A}} \\
530 \pm 7(111)^{\mathrm{A}} \\
514 \pm 14(49)^{\mathrm{A}} \\
516 \pm 16(40)^{\mathrm{A}} \\
511 \pm 23(34)^{\mathrm{A}}\end{array}$ \\
\hline $\begin{array}{l}15.0 \pm 0.2(51)^{\mathrm{C}} \\
10.8 \pm 0.1(142)^{\mathrm{A}} \\
10.5 \pm 0.2(62)^{\mathrm{A}} \\
12.1 \pm 0.1(130)^{\mathrm{B}} \\
12.3 \pm 0.2(76)^{\mathrm{B}}\end{array}$ & $\begin{array}{l}15.2 \pm 0.2(2)^{\mathrm{B}} \\
11.8 \pm 0.1(111)^{\mathrm{A}} \\
11.6 \pm 0.2(50)^{\mathrm{A}} \\
11.9 \pm 0.2(51)^{\mathrm{AB}} \\
11.7 \pm 0.9(34)^{\mathrm{A}}\end{array}$ \\
\hline $\begin{array}{l}-25.2 \pm 0.3(51)^{\mathrm{AB}} \\
-25.3 \pm 0.2(142)^{\mathrm{A}} \\
-24.2 \pm 0.3(62)^{\mathrm{BC}} \\
-23.8 \pm 0.2(130)^{\mathrm{C}} \\
-18.3 \pm 0.2(76)^{\mathrm{D}}\end{array}$ & $\begin{array}{l}-26.9 \pm 1.7(2)^{\mathrm{A}} \\
-23.8 \pm 0.2(111)^{\mathrm{C}} \\
-24.1 \pm 0.2(50)^{\mathrm{BC}} \\
-24.6 \pm 0.2(51)^{\mathrm{B}} \\
-18.2 \pm 0.3(33)^{\mathrm{D}}\end{array}$ \\
\hline $\begin{aligned}-2.6 \pm 0.2(50)^{\mathrm{A}} \\
5.2 \pm 0.3(142)^{\mathrm{C}} \\
5.4 \pm 0.3(62)^{\mathrm{C}} \\
1.5 \pm 0.3(129)^{\mathrm{B}} \\
4.9 \pm 0.4(77)^{\mathrm{C}}\end{aligned}$ & $\begin{array}{r}-2.7 \pm 0.5(2)^{\mathrm{A}} \\
7.1 \pm 0.2(111)^{\mathrm{C}} \\
6.5 \pm 0.3(50)^{\mathrm{C}} \\
4.0 \pm 0.5(51)^{\mathrm{B}} \\
4.8 \pm 0.6(33)^{\mathrm{B}}\end{array}$ \\
\hline
\end{tabular}

menhaden and bay anchovies. Silversides may seem an exception in that they were pelagic feeders with high $\mathrm{Hg}$ concentrations, but these fish are nearshore feeders and may selectively pick prey such as harpacticoid copepods from epiphyte surfaces (see FishBase [footnote 5] and Texas Freshwater Fishes, available online). ${ }^{6}$ In this case, silversides would be better classified as SAV-related in our study area. These ideas and the results shown in Fig. 4 point to the possible importance of SAV for supporting epiphyte communities and hotspots for entry of methylmercury into estuarine food webs.

The relatively large variability seen among grass shrimp composite samples and the 5-10× scatter in $\mathrm{Hg}$ values for individual young-of-the year largemouth bass at the $50-150 \mathrm{~mm}$ size ranges (Fig. 10) also can be explained by hotspot or high-Hg source regions. The

\footnotetext{
${ }^{6}$ http://www.bio.txstate.edu/ tbonner/txfishes/
}

alternative is that animals produce these divergent $\mathrm{Hg}$ values by markedly different diets, but shrimp and fish with high $\mathrm{Hg}$ values generally lacked accompanying distinctive $\mathrm{C}, \mathrm{N}$, or $\mathrm{S}$ isotope values. For this reason, $\mathrm{Hg}$ contents in fish such as largemouth bass (Fig. 10) may be much more related to source areas and hotspots and much less to age-associated bioaccumulation patterns. Further detailed investigations of nutrient effects on SAV development and $\mathrm{Hg}$ methylation are needed to better understand these patch dynamics, but some of our observations indicated that the types of SAV and food web structure could be important food web controls of $\mathrm{Hg}$ contents in fish.

Previous research in Louisiana has shown that adding river water to Louisiana estuaries stimulates SAV development, but not always the same types of SAV. The Mississippi River and its offshoot, the Atchafalaya River, both share high nutrient loads (Turner and Rabalais 1991), and studies of diversions at Breton Sound indicate that higher flows spread these nutrients throughout local estuaries (Lane et al. 2007, Day et al. 2009). The Atchafalaya River basin has water quality problems associated with Hydrilla beds that have developed with long-term river inputs, and especially near-anoxic conditions that develop in some backwaters when SAV beds die off and decay (Colon-Gaud et al. 2004). There may be a cycle of SAV growth when river stages are high and die-off when river stages fall, a cycle that is much less pronounced in Breton Sound, where water levels are much more even and the SAV community has developed into a mixed-species community not dominated by Hydrilla (Rozas et al. 2005). High river flows and tidal flushing may help prevent anoxic conditions from developing in Breton Sound, and generally SAV development can be beneficial to fisheries production. However, multivariate analyses of the fish community in Breton Sound indicated a simplification of food web structure for SAV beds in the path of the diversion (Rozas et al. 2005). These SAV beds are rich in epiphytes and grass shrimp described in several varieties of epiphyte-dependent food webs (Wissel and Fry 2005), with strongest diversion impacts in the areas sampled in this study. Lower epiphyte loads are thought to develop in dense Hydrilla beds of Louisiana when shading becomes important (Colon-Gaud et al. 2004). Comparisons of SAV communities in freshwater areas inside and outside the zone of nutrient-rich diversions made by Rozas et al. (2005) in Breton Sound would be consistent with the idea that diversions and associated river nutrients are supporting SAV development.

Our observations of upper Barataria systems in 2006 and 2007 after full operation of the Davis Pond diversion showed the establishment of dense Hydrilla beds in Lake Cataouatche, which was our study area closest to the diversion. Some centrarchids collected in this lake in 2007 had high $\delta^{13} \mathrm{C}$ values similar to the high $\delta^{13} \mathrm{C}$ values found in Breton Sound, but the Barataria fish still had low $\mathrm{Hg}$ concentrations. It is possible that 

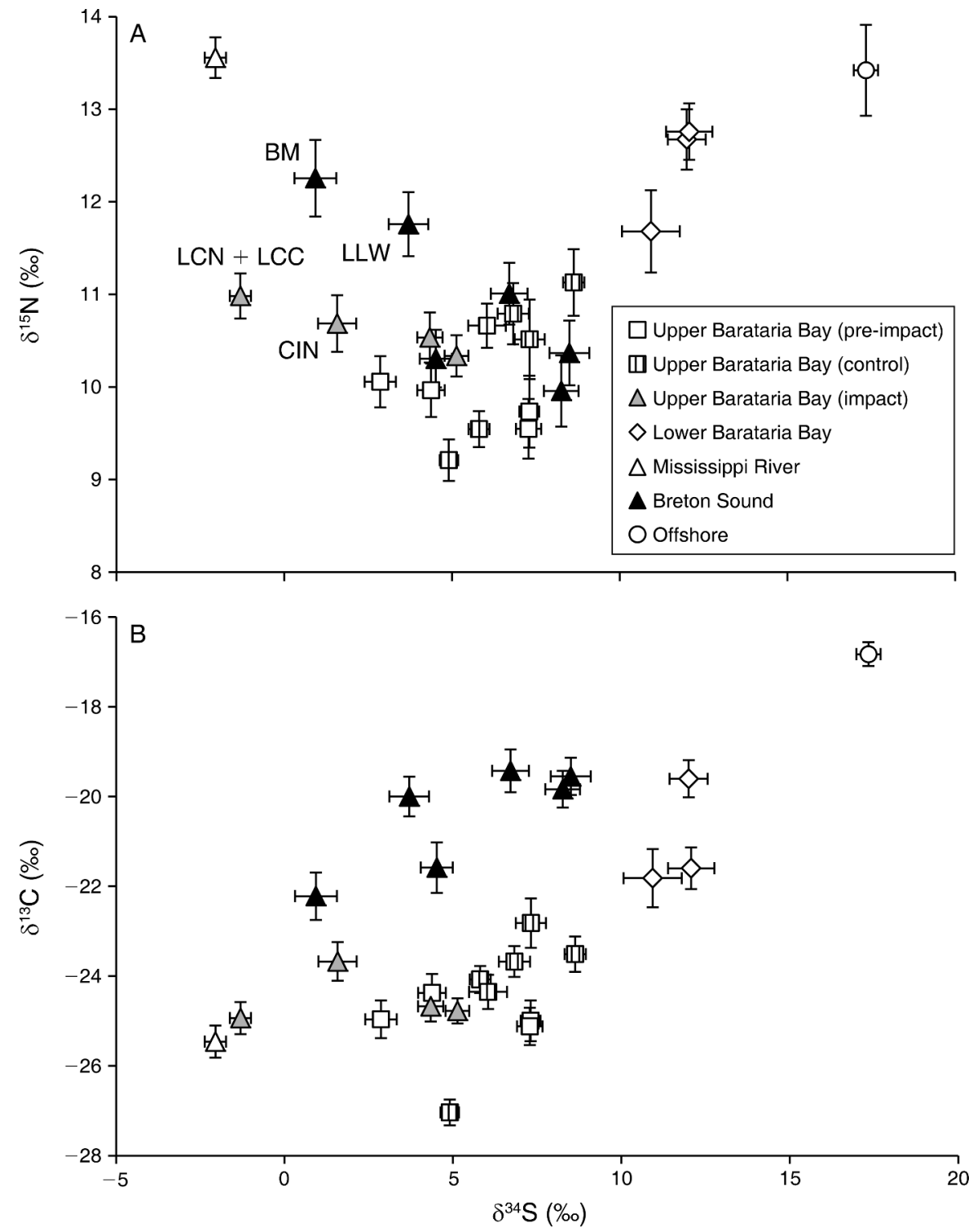

FIG. 7. Fish community averages $2003-2007$ by station group for (A) $\delta^{15} \mathrm{~N}$ vs. $\delta^{34} \mathrm{~S}$ and (B) $\delta^{13} \mathrm{C}$ vs. $\delta^{34} \mathrm{~S}$. See Fig. 1 for site abbreviations in panel A. Data are from Table 2. Error bars are $95 \%$ CL. Offshore samples are red snapper collected in a previous study (Wells et al. 2008a, b).

there was less loading of $\mathrm{Hg}$ into this system than to Breton Sound, and the presence of a holding pond area in upper Barataria Bay may be important in this regard. The holding pond is actually a cypress swamp that has developed a rich SAV community, and especially under lower-flow conditions this holding area reduces river nutrient contents ( $\mathrm{Yu}$ et al. 2006) and possibly $\mathrm{Hg}$ before river water enters Lake Cataouatche, where fish samples were collected in this study. Lower fish $\delta^{15} \mathrm{~N}$ values observed in near-diversion stations in upper Barataria Bay than in Breton Sound (Fig. 7, Barataria stations LCN + LCC and CIN vs. Breton Sound stations BM and LLW) would be consistent with greater nutrient removal and lessened nutrient loading arriving to Lake
Cataouatche (Schlacher et al. 2005, DeLaune et al. 2008). However, long-term loading of nutrients from the river may yet result in increased $\mathrm{Hg}$ levels for upper Barataria fish, with emergence of extensive SAV beds by the summer of 2006 an early symptom. In addition to relatively low cumulative nutrient loading experienced thus far in comparison to upper Breton Sound, local food webs in upper Barataria Bay may not yet have developed into those resulting in high fish $\mathrm{Hg}$ contents. Specifically, in our 2006-2007 sampling, the Hydrilla beds in Lake Cataouatche appeared relatively fresh, green, and free of epiphytes, and may not have supported the same community of small animals and grass shrimp that are the likely basis of food webs in 

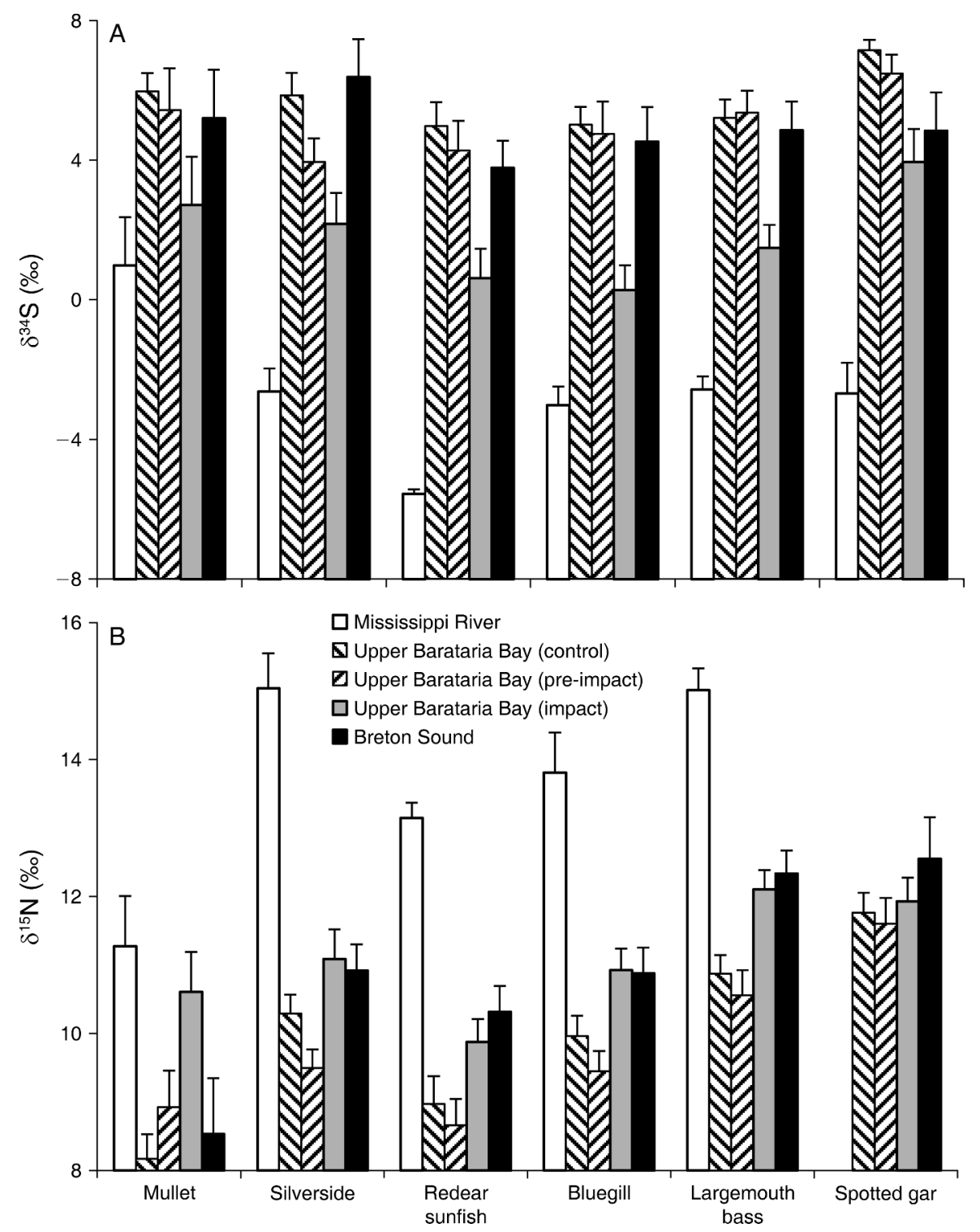

FIG. 8. Site comparisons for six species collected at upper-estuary stations: (A) $\delta^{34} \mathrm{~S}$ and (B) $\delta^{15} \mathrm{~N}$. Data are from Table 2. Mullet include both striped and white mullet. Error bars are 95\% CL.

Breton Sound. An alternate prey base for upper Barataria Bay is benthic animals, and throughout this study, fish such as mullet and gizzard shad that feed from the benthos consistently had low $\mathrm{Hg}$ concentrations: $<100 \mathrm{ng} / \mathrm{g}$, even for large individuals of 250-500 $\mathrm{mm}$ total length. It is possible that decaying Hydrilla communities currently are supporting this type of benthic prey base in Lake Cataouatche, accounting for the high $\delta^{13} \mathrm{C}$ and low $\mathrm{Hg}$ concentrations measured in the 2007 centrarchids from Lake Cataouatche. Further sampling in the next 5-10 years can test for convergence of all chemical markers ( $\mathrm{Hg}+$ isotopes) in the upper Barataria and upper Breton Sound food webs, a convergence expected when epiphyte-based food webs dominate both areas.

Continued sampling in Breton Sound can also test alternative ideas about $\mathrm{Hg}$ cycling, e.g., that pumped stormwater inputs might be affecting $\mathrm{Hg}$ in fish food webs. Work to date suggests that pumped stormwater inputs are a minor part of Breton Sound hydrology at $4-11 \%$ of water inputs vs. $33-48 \%$ for diversion inputs (Hyfield et al. 2008), and that these stormwater flows affect mostly margins of the study region rather than more centrally located sites that were sampled in this study in the path of main diversion flows. Measurements of $\mathrm{C}, \mathrm{N}$, and $\mathrm{S}$ isotopes show that community composition and standing stocks at our sample stations 


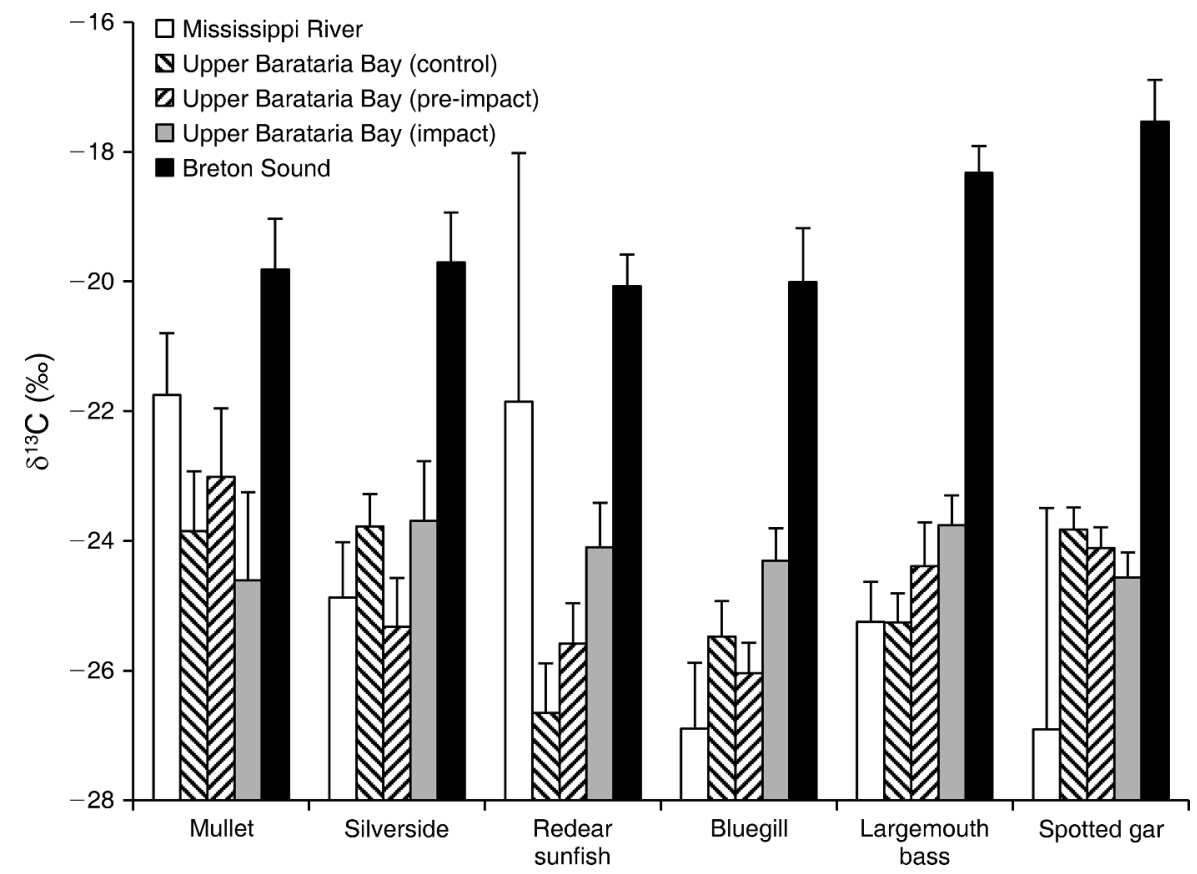

FIG. 9. Site comparisons of $\delta^{13} \mathrm{C}$ values for six species collected at upper-estuary stations. Error bars are $95 \% \mathrm{CL}$. Data are from Table 2.
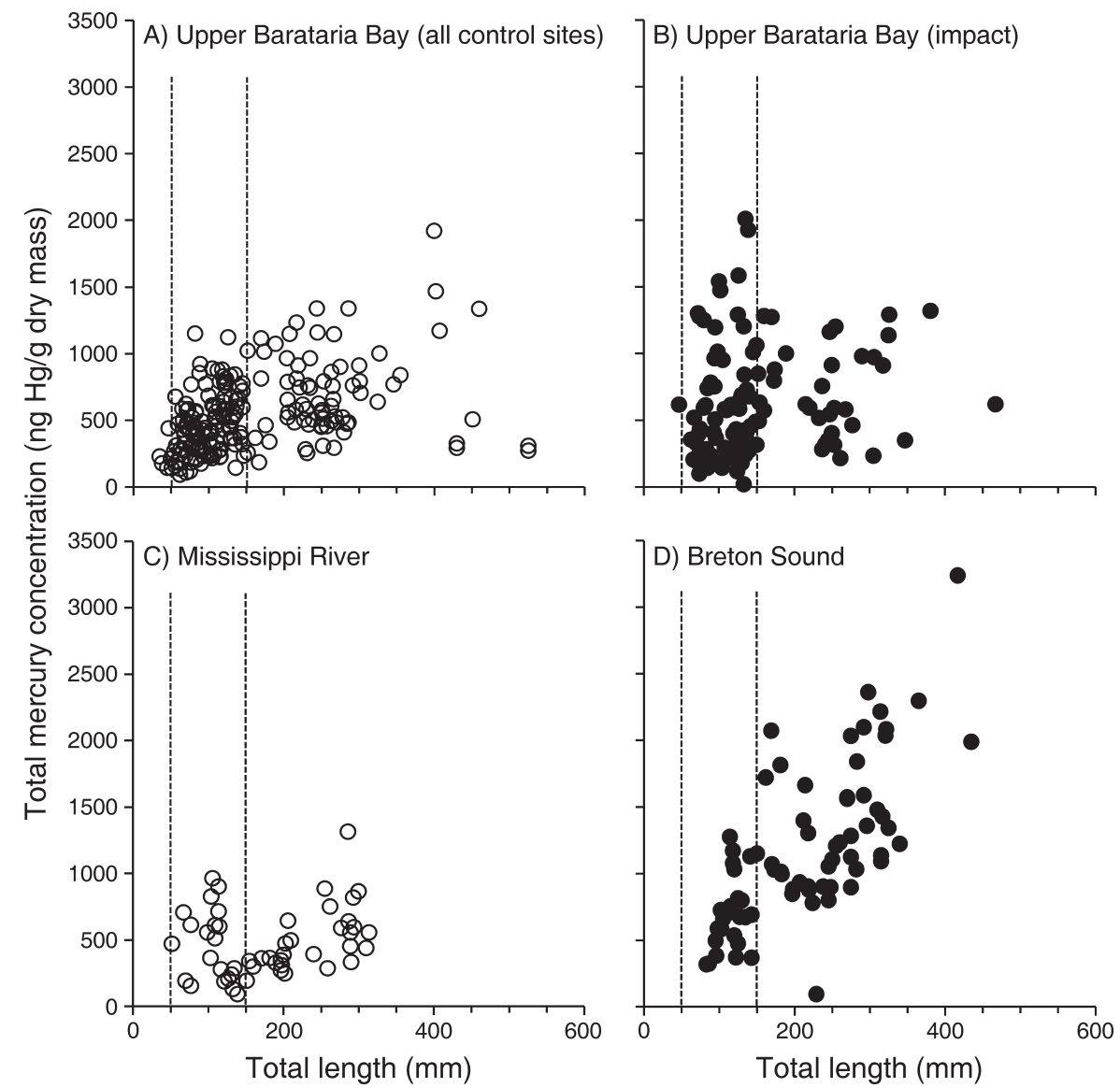

FIG. 10. Hg contents of largemouth bass by size from four study areas. Vertical dashed lines bracket data for $50-150 \mathrm{~mm}$ fish. 
are strongly affected by river nutrient inputs (Rozas et al. 2005, Wissel and Fry 2005, Wissel et al. 2005), and enhanced $\mathrm{Hg}$ bioaccumulation is consistent with high $\mathrm{Hg}$ concentrations in very abundant local grass shrimp (as we found). Nonetheless, we lacked pre-diversion $\mathrm{Hg}$ data for these Breton Sound sites and relied on the prediversion Barataria data (Fig. 6) for the regional $\mathrm{Hg}$ background. This reliance seems reasonable because the Barataria and Breton Sound estuaries are similar in many regards (Wissel et al. 2005) and both estuaries generally have low fish $\mathrm{Hg}$ concentrations when compared to other parts of Louisiana (Katner et al. 2010).

Mercury concentrations in individual fish analyzed in this study were generally low (the maximum value was $3240 \mathrm{ng} / \mathrm{g})$ and rarely exceeded $1500 \mathrm{ng} / \mathrm{g}(\sim 300 \mathrm{ng} / \mathrm{g}$ wet) concentration values that are the current EPA threshold of concern for $\mathrm{Hg}$ problems in fish (U.S. EPA 2001). Most (91\%) of the fish exceeding this $1500 \mathrm{ng} / \mathrm{g}$ limit were spotted gar and largemouth bass from diversion-impacted sites in upper Breton Sound and upper Barataria Bay, but altogether, these fish accounted for only $2.5 \%$ of the total 2168 Louisiana estuarine fish sampled in this study. However, lower $\mathrm{Hg}$ thresholds than those acceptable for human health may still affect ecosystem function and further research is needed to determine what $\mathrm{Hg}$ levels are really background and acceptable in natural systems. In this regard, average fish community $\mathrm{Hg}$ values of $351 \mathrm{ng} / \mathrm{g}$ ( $75 \mathrm{ng} / \mathrm{g}$ wet) were documented in upper-estuary areas unimpacted by diversions, and this may be considered a preliminary estimate of average $\mathrm{Hg}$ background concentrations for Louisiana estuarine fish. For largemouth bass from these same unimpacted areas (Fig. 10A), the average was $550 \pm 20 \mathrm{ng} / \mathrm{g}$ dry mass (mean $\pm \mathrm{SE}, N=260$ ) and was not different from the average given in Katner et al. (2010, their Fig. 4A) for largemouth bass from these same areas. We measured a lower community average value of $149 \mathrm{ng} / \mathrm{g}(\sim 32 \mathrm{ng} / \mathrm{g}$ wet) for three stations in lower Barataria Bay (Fig. 3), and this may apply as a community average background value for marine portions of estuaries. Surveys of fauna from salt marsh ponds of Terrebonne Bay showed lowest average $\mathrm{Hg}$ levels of 54 and $20 \mathrm{ng} / \mathrm{g}$ (11 and $4 \mathrm{ng} / \mathrm{g}$ wet) for fish and shrimp, respectively. Katner et al. (2010) similarly found lower $\mathrm{Hg}$ values in brackish portions of Louisiana estuaries.

We found that benthic fish that feed on animals in sediments generally had the lowest fish $\mathrm{Hg}$ concentrations. Strong sulfate reduction in sediments usually leads to substantial accumulation of sulfides that can bind and trap $\mathrm{Hg}$, and perhaps this trapping prevents further methylation and bioaccumulation of $\mathrm{Hg}$ in food webs. Sulfate reduction in salt marsh sediments is very active in producing copious sulfides (e.g., Howarth and Giblin 1983), and sulfide trapping of $\mathrm{Hg}$ may explain why animals from a salt marsh pond and adjacent bay had the lowest $\mathrm{Hg}$ levels measured in this study.
Our findings of low $\mathrm{Hg}$ concentrations for these salt marsh animals and, generally, in fish from the highsalinity, marine end of estuaries like Barataria Bay (Fig. 3) do not support the speculation advanced by Hall et al. (2008) that estuaries could be source regions for high $\mathrm{Hg}$ concentrations in offshore fish. Rather, we agree with suggestions in other recent studies (Cossa et al. 2009, Sunderland et al. 2009, Senn et al. 2010) that low-oxygen conditions in offshore marine snow and in oceanic oxygen minimum zones may provide favorable conditions for in situ source regions for $\mathrm{Hg}$ methylation and $\mathrm{Hg}$ incorporation into offshore food webs.

We found that fish mercury concentrations in some species such as largemouth bass were quite variable, and that sampling three composites of 15 small $50-150 \mathrm{~mm}$ fish is a statistically powerful way to detect significant $\mathrm{Hg}$ differences among sites. The recommendation to use three composites is similar to that developed in a previous study of marsh fish (Fry et al. 2008), and use of composites may be needed for benthic fish that often show strong between-individual variation in chemical parameters such as stable isotopes (Fry et al. 1999) or $\mathrm{Hg}$ (as we found in this study). Most Hg-related fish programs currently focus on sampling a few large individual fish to characterize sites, mostly because such large fish are potentially consumed by humans. However, a focus on using composites of many small fish may be a statistically more powerful way to detect site differences and to monitor attempts to decrease $\mathrm{Hg}$ bioaccumulation in coastal fisheries.

\section{ACKNOWLEDGMENTS}

This work was supported by NOAA MULTISTRESS award 16OP2670, by project development funds from Louisiana SeaGrant, by NOAA Coastal Ocean Program grants NA06NOS4780141 and NA09NOS4780204, and by NOAA grant 412 NA06OAR4320264 06111039 to the Northern Gulf Institute. Sunil Addepalli, Pamela MacRae, Gary Peterson, Zoraida Quinones, Barack Bhallam Venkaat, and Bjoern Wissel assisted with fisheries collections. Louisiana State University undergraduates Elizabeth Ecker, Elizabeth Gallagher, Madeleine Grant, Tracy Pasqua, Rebecca Sylvestri, and Julia Wheatley helped with laboratory preparation of samples. Texan Christian University undergraduate Niki Long assisted with mercury analysis. R. P. Gambrell analyzed initial samples of grass shrimp for this study, and Sara Green helped with observations concerning development of SAV communities in Lake Cataouatche.

\section{Literature Cited}

Bates, A. L., W. H. Orem, J. W. Harvey, and E. C. Spiker. 2002. Tracing sources of sulfur in the Florida Everglades. Journal of Environmental Quality 31:287-299.

Benoit, J. M., C. C. Gilmour, R. P. Mason, and A. Heyes. 1999. Sulfide controls on mercury speciation and bioavailability to methylating bacteria in sediment pore waters. Environmental Science and Technology 33:951-957.

Benoit, J. M., C. C. Gilmour, R. P. Mason, G. S. Riedel, and G. F. Riedel. 1998. Behavior of mercury in the Patuxent River estuary. Biogeochemistry 40:249-265.

Bryan, C. F., D. A. Rutherford, and B. Walker-Bryan. 1992. Acidification of the lower Mississippi River. Transactions of the American Fisheries Society 121:369-377. 
Chumchal, M. M., R. W. Drenner, B. Fry, K. D. Hambright, and L. W. Newland. 2008. Habitat-specific differences in mercury concentrations of largemouth bass (Micropterus salmoides) from Caddo Lake, Texas. Transactions of the American Fisheries Society 137:195-208.

Chumchal, M. M., and K. D. Hambright. 2009. Ecological factors regulating mercury contamination of fish from Caddo Lake, Texas, USA. Environmental Toxicology and Chemistry 28:962-972.

Cizdziel, J. V., T. A. Hinners, and E. M. Heithmar. 2002. Determination of total mercury in fish tissues using combustion atomic absorption spectrometry with gold amalgamation. Water, Air, and Soil Pollution 135:355-370.

Cleckner, L. B., P. J. Garrison, J. P. Hurley, M. L. Olson, and D. P. Krabbenhoft. 1998. Trophic transfer of methyl mercury in the northern Florida Everglades. Biogeochemistry 40:347361.

Cleckner, L. B., C. C. Gilmour, J. P. Hurley, and D. P. Krabbenhoft. 1999. Mercury methylation in periphyton of the Florida Everglades. Limnology and Oceanography 44:1815-1825.

Colon-Gaud, J. C., W. E. Kelso, and D. A. Rutherford. 2004. Spatial distribution of macroinvertebrates inhabiting Hydrilla and Coontail beds in the Atchafalaya Basin, Louisiana. Journal of Aquatic Plant Management 42:85-91.

Cossa, D., B. Averty, and N. Pirrone. 2009. The origin of methylmercury in open Mediterranean waters. Limnology and Oceanography 54:837-844.

Day, J. W., et al. 2009. The impacts of pulsed reintroduction of river water on a Mississippi delta coastal basin. Journal of Coastal Research 54:225-243.

DeLaune, R. D., C. W. Lindau, and A. Jugsujinda. 2008. Indicators for evaluating the influence of diverted Mississippi River water on Louisiana coastal marsh. Journal of Freshwater Ecology 23:475-477.

Drenner, R. W., M. M. Chumchal, S. P. Wente, M. McGuire, and S. M. Drenner. 2011. Landscape-level patterns of mercury contamination of fish in North Texas. Environmental Toxicology and Chemistry 30:2041-2045.

Driscoll, C. T., Y. Han, C. Y. Chen, D. C. Evers, K. F. Lambert, T. M. Holsen, N. C. Kamman, and R. K. Munson. 2007. Mercury contamination in forest and freshwater ecosystems in the northeastern United States. BioScience 57:17-28.

Fremling, C. R., J. L. Rasmussen, R. E. Sparks, S. P. Cobb, C. F. Bryan, and T. O. Claflin. 1989. Mississippi River fisheries: a case history. Canadian Journal of Fisheries and Aquatic Sciences 106:309-351.

Fry, B. 2002a. Conservative mixing of stable isotopes across estuarine salinity gradients: a conceptual framework for monitoring watershed influences on downstream fisheries production. Estuaries 25:264-271.

Fry, B. 2002b. Stable isotope indicators of habitat use by Mississippi River fish. Journal of the North American Benthological Society 21:676-685.

Fry, B. 2006. Stable isotope ecology. Springer, New York, New York, USA.

Fry, B. 2007. Coupled N, C, and S isotope measurements using a dual column GC system. Rapid Communications in Mass Spectrometry 21:750-756.

Fry, B. 2008. Importance of open bays as nurseries for Louisiana brown shrimp. Estuaries and Coasts 31:776-789.

Fry, B., D. Baltz, M. Benfield, J. Fleeger, A. Gace, H. A. Haas, and Z. Quinones. 2003. Chemical indicators of movement and residency for brown shrimp (Farfantepenaeus aztecus) in coastal Louisiana marshscapes. Estuaries 26:82-97.

Fry, B., and M. M. Chumchal. 2011. Sulfur stable isotope indicators of residency in estuarine fish. Limnology and Oceanography 56:1563-1576.

Fry, B., M. Cieri, J. Hughes, C. Tobias, L. A. Deegan, and B. Peterson. 2008. Stable isotope monitoring of benthic-pelagic coupling with salt marsh fish. Marine Ecology Progress Series 369:193-204.

Fry, B., P. L. Mumford, F. Tam, D. D. Fox, G. L. Warren, K. E. Havens, and A. L. Steinman. 1999. Trophic position and individual feeding histories of fish from Lake Okeechobee, Florida. Canadian Journal of Fisheries and Aquatic Sciences 56:590-600.

Gaffney, O. 2009. A planet on the edge. Global Change 74:1013.

Green, S., E. Swenson, and B. Fry. 2007. Effects of river inputs on nutrient cycling of submerged aquatic vegetation in Lake Cataouatche, Louisiana. Abstract SCI-076, Providence RI meeting of the Estuarine Research Foundation, November 2007. Estuarine Research Federation, Providence, Rhode Island, USA.

Hall, B. D., G. R. Aiken, D. P. Krabbenhoft, M. MarvinDiPasquale, and C. M. Swarzenski. 2008. Wetlands as principal zones of methylmercury production in southern Louisiana and the Gulf of Mexico region. Environmental Pollution 154:124-34.

Hall, B. D., R. A. Bodaly, R. J. P. Fudge, J. W. M. Rudd, and D. M. Rosenberg. 1997. Food as the dominant pathway of methylmercury uptake by fish. Water, Air, and Soil Pollution 100:13-24.

Howarth, R. W., and A. Giblin. 1983. Sulfate reduction in the salt marshes at Sapelo Island, Georgia. Limnology and Oceanography 28:70-82.

Hyfield, E. C. G., J. W. Day, J. E. Cable, and D. Justic. 2008. The impacts of re-introducing Mississippi River water on the hydrologic budget and nutrient inputs of a deltaic estuary. Ecological Engineering 32:347-359.

Katner, A., M.-H. Sun, and M. Suffet. 2010. An evaluation of mercury levels in Louisiana fish: trends and public health issues. Science of the Total Environment 408:5707-5714.

Kidd, K. A. 1998. Use of stable isotope ratios in freshwater and marine biomagnification studies. Pages 357-376 in J. Rose, editor. Environmental toxicology: current developments. Gordon and Breach Science Publishers, Amsterdam, The Netherlands.

Kongchum, M., I. Devai, R. D. DeLaune, and A. Jugsujinda. 2004. Total mercury and methylmercury in freshwater and salt marsh soils of the Mississippi river deltaic plain. Chemosphere 63:1300-1303.

Kuhl, M., and B. B. Jorgensen. 1992. Microsensor measurements of sulfate reduction and sulfide oxidation in compact microbial communities of aerobic biofilms. Applied and Environmental Microbiology 58:1164-1174.

Lane, R., J. W. Day, B. Marx, E. Reyes, E. Hyfield, and J. N. Day. 2007. The effects of riverine discharge on temperature, suspended sediments, and chlorophyll $a$ in a Misssissippi delta estuary measured using a flow-through system. Estuarine and Coastal Shelf Science 74:145-154.

Leaner, J. J., and R. P. Mason. 2002. Factors controlling the bioavailability of ingested methylmercury to channel catfish and Atlantic sturgeon. Environmental Science and Technology 36:5124-5129.

Meade, R. H. 1995. Contaminants in the Mississippi River, 1987-1992. Circular 1133. U.S. Geological Survey, Reston, Virginia, USA.

Minagawa, M., and E. Wada. 1984. Stepwise enrichment of ${ }^{15} \mathrm{~N}$ along food chains: Further evidence and the relation between $\delta^{15} \mathrm{~N}$ and animal age. Geochimica et Cosmochimica Acta 48:1135-1140.

Mitchell, C. P. J., B. A. Branfireun, and R. K. Kolka. 2008. Spatial characteristics of net methylmercury production hot spots in peatlands. Environmental Science and Technology 42:1010-1016.

NRC [National Research Council]. 2000. Toxicological effects of methylmercury. National Academy Press, Washington, D.C., USA. 
Pacyna, E. G., and J. M. Pacyna. 2002. Global emission of mercury from anthropogenic sources in 1995. Water, Air, and Soil Pollution 137:149-165.

Porcella, D. B. 1994. Mercury in the Environment: Biogeochemistry. Pages 3-20 in C. J. Watras and J. W. Huckabee, editors. Mercury pollution: integration and synthesis. Lewis Publishers, Boca Raton, Florida, USA.

Rice, G. E., D. B. Senn, and J. P. Shine. 2009. Relative importance of atmospheric and riverine mercury sources to the Northern Gulf of Mexico. Environmental Science and Technology 43:415-422.

Rozas, L. P., T. J. Minello, I. Munyera-Fernandez, B. Fry, and B. Wissel. 2005. Macrofaunal distributions and habitat change following winter-spring releases of freshwater into the Breton Sound Estuary, Louisiana (USA). Estuarine, Coastal and Shelf Science 65:319-336.

Schlacher, T. A., B. Liddell, T. F. Gaston, and M. SchlacherHoenlinger. 2005. Fish track wastewater pollution to estuaries. Oecologia 144:570-584.

Senn, D. B., E. Chesney, J. D. Blum, M. S. Bank, A. Maage, and J. P. Shine. 2010. Stable isotope study (C, N, Hg) of methylmercury sources and trophic transfer in the Northern Gulf of Mexico. Environmental Science and Technology 44:1630-1637.

StatPoint Technologies. 2008. Statgraphics Plus. Version 5.1. StatPoint Technologies, Warrenton, Virginia, USA.

Sunderland, E. M., D. P. Krabbenhoft, J. W. Moreau, S. A. Strode, and W. M. Landing. 2009. Mercury sources, distribution, and bioavailability in the North Pacific Ocean: Insights from data and models. Global Biogeochemical Cycles 23:GB2010.

Turner, R. E. 2009. Doubt and the values of an ignorancebased world view for restoration: coastal Louisiana wetlands. Estuaries and Coasts 32:1054-1068.

Turner, R. E., and M. E. Boyer. 1997. Mississippi River diversions, coastal wetland restoration/creation and an economy of scale. Ecological Engineering 8:117-128.

Turner, R. E., and N. N. Rabalais. 1991. Changes in Mississippi River water quality this century and implications for coastal food webs. BioScience 41:140-147.

Turner, R. E., N. N. Rabalais, R. B. Alexander, G. McIsaac, and R. W. Howarth. 2007. Characterization of nutrient, organic carbon, and sediment loads and concentrations from the Mississippi River into the Northern Gulf of Mexico. Estuaries and Coasts 30:773-790.

Ullrich, S. M., T. W. Tanton, and S. A. Abdrashitova. 2001. Mercury in the aquatic environment: a review of factors affecting methylation. Critical Reviews in Environmental Science and Technology 31:241-293.

U.S. EPA [U.S. Environmental Protection Agency]. 1998. Method 7473: mercury in solids and solutions by thermal decomposition, amalgamation and atomic absorption spectrophotometry. U.S. EPA, Washington, D.C., USA.

U.S. EPA [U.S. Environmental Protection Agency]. 2001. Water quality criterion for the protection of human health: methylmercury. Final Report EPA-823-R-01-001. U.S. EPA, Washington, D.C., USA.

Vander Zanden, M. J., and J. B. Rasmussen. 2001. Variation in $\delta^{15} \mathrm{~N}$ and $\delta^{13} \mathrm{C}$ trophic fractionation: Implications for aquatic food web studies. Limnology and Oceanography 46:20612066.

Wells, R. J. D., M. M. Chumchal, and J. H. Cowan, Jr. $2008 a$. Effect of trawling and habitat on mercury concentration in juvenile red snapper from the Northern Gulf of Mexico. Transactions of the American Fisheries Society 137:18391850.

Wells, R. J. D., J. H. Cowan, Jr., and B. Fry. 2008b. Feeding ecology of red snapper, Lutjanus campechanus, in the northern Gulf of Mexico. Marine Ecology Progress Series 361:213-225.

Wiener, J. G., D. P. Krabbenhoft, G. H. Heinz, and A. M. Scheuhammer. 2003. Ecotoxicology of mercury. Pages 409463 in D. J. Hoffman, B. A. Rattner, G. A. Burton, Jr., and J. Cairns, Jr., editors. Handbook of ecotoxicology. Second edition. Lewis Publishers, Boca Raton, Florida, USA.

Wissel, B., and B. Fry. 2005. Tracing Mississippi River influences in estuarine food webs of coastal Louisiana. Oecologia 144:659-672.

Wissel, B., A. Gace, and B. Fry. 2005. Tracing river influences on phytoplankton dynamics in two Louisiana estuaries. Ecology 86:2751-2762.

Yu, K. W., R. D. DeLaune, and P. Boeckx. 2006. Direct measurement of denitrification activity in a Gulf coast freshwater marsh receiving diverted Mississippi River water. Chemosphere 65:2449-2455. 